\title{
大阪市空堀地区における路地単位特性と 接道不良長屋所有者の居住改善実態 \\ 一木造密集市街地における地域資源を活かした住環境の保全的更新に関する研究一 \\ CHARACTERISTICS OF ALLEY UNITS AND OWNER IMPROVEMENTS OF ROW HOUSES WITH ROAD CONTACT FAILURE IN KARAHORI, OSAKA \\ - Study of upkeep and renewal of the living environments utilized the regional resources in densely built-up area with wooden buildings -
}

\section{原田陽子*}

\section{Yoko HARADA}

\begin{abstract}
This study clarifies the characteristics of alley units and owner improvements of row houses with road contact failure in the Osaka Karahori area. The following are major findings.

1) The alley units which have small shrine or Jizo, ups and down, and blind alley, have tendency there are many individual regional resources. And small shrine and Jizo is important resource to continue the community within the alley unit.

2) Owners of row houses with road contact failure realize the living improvement by five classified methods on the basis such as individual spatial terms and living demands.
\end{abstract}

Keywords: $\quad$ Densely built-up area with wooden buildings, Row house with road contact failure, Characteristic of alley unit, Regional resource, Improvement dwelling, Upkeep and renewal 木造密集市街地，接道不良長屋，路地単位特性，地域資源，居住改善，保全的更新

\section{1. 研究の背景と目的・方法}

\section{1-1. 研究の背景と目的}

空堀地区は大阪市中央区に位置し、商業・工業・住宅が混在する 交通面でも利便性の高い地区である。一方で地区内には戦災を免れ た長屋が数多く残り、起伏に富んだ地形条件であることから石畳の 階段や坂等も多く変化に富んだ景観を持ち、長屋が面する路地沿い には祠や地蔵、冠木門などが点在し大都市都心部でありながら歴史 的地域資源が数多く残る。2001 年以降、地元まちづくり団体による 長屋等を活用した複合商業施設やアートイベントなど様々な活動が 行われ、このような動きと共に、近年ではまちづくり団体とは別に、 個人で大家と契約した新規流入者による長屋等を活かした店舗や ギャラリー、事務所、住居としての利用も地区内に増加してきている。

しかし一方で空堀地区では近年、居住者の高齢化と共に長屋の老 朽化や空き家、空地が目立ち、幹線道路沿いのみならず街区内部に ある長屋群や路地の取り壊しによる高層マンション建設が進行して いる。さらに空堀地区には、いわゆる裏長屋と呼ばれる「接道不良 の長屋」注1) が数多く存在する。このような長屋では、建設から数十 年を経て隣戸と壁を共有したまま切り売りされ住戸単位での所有も 多く、また狭小でかつ $4 \mathrm{~m}$ 以上の道路に接していないため世帯単位て 建替をすることが難しい状況にある。

以上のように空堀地区では、高層マンション建設など空間面での 大きな変化や新規流入者による長屋の活用など新しい動きが見られ る一方で、街区内部の接道不良長屋では多くの問題を抱えた状態で
ある。また空堀地区は場所によって様々な条件の違いを持つため、 接道不良長屋の住環境の改善を考えるにあたっては、地形条件や街 路形態、地域資源の分布など路地ごとの特性（以下、路地単位特性） を把握すると共に、接道不良長屋所有者の居住実態や意向を把握す る必要があると考えられる。

本研究に関連する既往研究としては、これまでにいくつもの有益 な研究が行われている。まず関西での路地特性に関する研究として、 大阪・谷町における長屋街区形成過程に関する増井らの研究 ${ }^{1)}$ 、京都 の路地空間や街区の特性に関する高木ら ${ }^{2)}$ の研究、空堀地区における 町屋と祠の変遷に関する川窪による研究 ${ }^{3)}$ 、祠や地蔵などを含めた路 地でのコミュニティに関する吉野による研究 ${ }^{4)}$ がある。

また歴史的なまちなみを持つ密集市街地などでの保全的更新の可 能性を示すものとして、東京都月島地区において路地保全を目指し 3 項道路型地区計画の実績と効果を考察した川崎の研究 ${ }^{5)}$ や、街なみ 環境整備事業が適用された長野県木曽町を対象に効果的な路地空間 の保全を可能とする要件を考察した丸登らの研究 ${ }^{6)}$ 、良好な住環境 整備や地区計画策定などのためのデザインガイドのあり方を考察し た高野らの研究 ${ }^{7)}$ がある。

一方、木造密集市街地における市街地特性や居住実態に関する研 究として、墨田区向島地区における市街地更新実態と地域内住み替 え実態との関係性を考察した真野らの研究 ${ }^{8)}$ や建築更新活動と家族 の居住継承に関寸る松本の研究 ${ }^{9)}$ がある。

さらに密集市街地の更新手法の可能性に関する研究として、連担

\footnotetext{
$*$ 福井大学大学院工学研究科 助教 $\cdot$ 博士 (芸術工学)
}

Assistant Prof., Graduate School of Engineering, University of Fukui, Dr. Design Research 
建築物設計制度の運用に関する金らの研究 ${ }^{10)}$ や協調的個別更新の可 能性を考察した田中の研究 ${ }^{11)}$ 、協調建替に関寸る小林らの研究 ${ }^{12}$ 、 神戸市の複数地区を対象に協調的住環境改善手法の適用条件を考察 した藤井らの研究 ${ }^{13)}$ などがある。また近年の新規流入者による既存 の建物活用等の可能性に関連するものでは、大阪市中崎町における 長屋等を利用したコンバージョン事例に関する研究 ${ }^{14)}$ などがある。

しかし木造密集市街地において、路地単位特性や街区内部の接道 不良長屋に着目し、接道不良長屋所有者の居住改善実態などを通し て、地域資源を活かした住環境の保全的更新の課題について考察し た研究は無いのが現状である。

そこで本研究では大阪市空堀地区における「(1)空間特性と路地単 位特性」「(2)接道不良長屋所有者の居住改善実態」「(3)接道不良長屋 所有者の今後の改善・継承意向と新規流入者の長屋等の利用概要」 の把握を通して、木造密集市街地における地域資源を活かした住環 境の保全的更新に向けた課題と可能性を探ることを目的とする。

\section{1-2. 研究の方法}

このため本研究では以下のように論を進める。

第 1 に、空堀地区における路地と接道不良長屋の分布、高層建築 物の建設状況、空地・空き家の分布から、空堀地区全体の空間特性 の把握を行う。そして大阪市が HOPE ゾーン事業策定の際に設定した 55 の路地単位を対象として（図 1） 注2)、長屋数、地形条件、祠・地 蔵など地域資源の分布の把握を行なうと共に、「11地蔵・祠の有無」、 「(2)坂・高低差の有無」、「(3)袋小路の有無」の 3 つの視点から 55 の 路地単位の類型化を行う。そして類型の異なる複数の路地単位を抽 出して以前と現在のコミュニティの状況を把握し、これらをもとに 路地単位特性の把握を行う。

第 2 に、55 の路地単位内における接道不良長屋所有者へのヒアリ ング調査により、増改築など居住改善実態の把握を行なう。そして、 居住改善手法の分類を行い、分類ごとの改善の動機や利用内容、接 道条件や路地単位特性との関係などを考察する。

第 3 に、接道不良長屋所有者の今後の長屋の改善・継承意向の把 握と、新規流入者による流入動向と長屋等の利用の概要把握を行な い、最終的には上記 1 - 3 の結果を基に、地域資源を活かした住環 境の保全的更新に向けた課題と可能性の考察を行なう。

\section{1-3. 用語の定義}

なお本研究では、以下のように用語を定義する。

【地域資源】：「地域資源」には人的資源など様々な資源が考えられる

(○で囲んだ路地単位は 3 章 3-3 で対象とする 20 の路地単位)

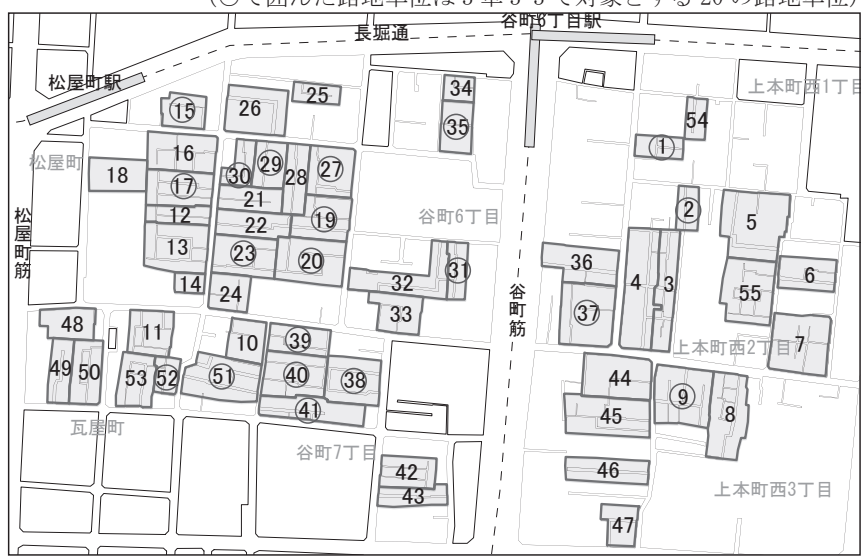

図 1 設定した 55 の路地単位の位置
が、本研究における「地域資源」とは、立地条件や地形条件、長屋 や路地、地蔵、祠、冠木門、石畳や石階段など、空堀地区の固有性 を特徵付けている特に空間に関する資源を指すものとする注3)

【保全的更新】：現況の路地の幅員やしつらえの尊重、耐震防災を前 提にしつつ地域資源による歴史的風情を継承した既存の木造建物の 改修・増改築や耐火建築物による中低層高密住宅への建替も含まれ る。また建物の更新だけでなく路地など屋外空間の整備も含まれる。 【地域資源を活かした住環境の保全的更新】：立地条件、路地や長屋 の持つ風情等その建物を取り巻く地域資源を活かすことにより、既 存の路地や地域にとって新たな価值が付加されるような更新を指す。

\section{2. 調査と対象地の概要}

\section{2-1. 調査の概要}

本研究では以下の 3 つの調查を軸に分析を進めた。

（1）空堀地区の空間特性と路地単位特性に関する調査

現地での目視調査、住宅地図や人口統計資料、道路台帳、大阪市 が作成した HOPE ゾーン事業の関連資料等を通して、空堀地区におけ る街路種別、接道不良長屋の分布、土地利用の状況、高層建築物の 建設状況などの把握を行なった。また、空堀地区の町会役員や HOPE ゾーン協議会役員へのヒアリングを行なうと共に、55の路地単位の 中から、地形条件や街路形態、長屋や個別の地域資源の分布などに おいて特徴を持つ 20 の路地単位を抽出し、各路地単位の居住者 59 人に対し、路地単位内でのコミュニティ活動に関するヒアリング調 查を行った (2009 年 10 月ー 2009 年 12 月、補足調查 2011 年 2 月)。 （2）接道不良長屋所有者の居住実態に関する調査（表 1)

空堀地区内において長屋を所有している 107 人（所有長屋数合計 132 戸)へのヒアリング調查を実施した（2008 年 12 月ー 2009 年 1 月、 補足調查 2009 年 10 月- 11 月)。なお本研究ではこの内、所有者自 身が接道不良長屋を利用している 85 人と、その 85 人が所有してい る接道不良長屋 99 戸を対象に分析を行なう。

（3）新規流入者の長屋等の利用概要に関する調查（表 2)

さらに接道不良長屋の今後の保全的更新の可能性を考えるにあた り、近年空堀地区内の長屋を利用した新規流入者 77 人に対し、建物 利用の動機など物件入手のプロセスに関するヒアリング調查を実施 した (2010年 6 月一 2010 年 8 月、補足調查 2010 年 11 月一 2011 年 1 月)。 なお本研究では接道不良長屋の保全的更新の可能性に着目するため、 分析対象を新規流入者の定義に合致し、かつ既存建物を個人で大家 と直接契約し活用している合計 45 件に絞って分析を行う注4)

\section{2-2. 空堀地区の概要}

本研究対象地である空堀地区は図 2 に示寸面積約 36ha の範囲で、 人口 8281 人、4617 世帯となっている (H22 年度国勢調查)。上町台 地に位置し起伏に富んだ地形条件であることから、地区内には石畳 の階段や坂等も多く変化に富んだ景観を持つ。まちの中心には東西

表 1 長屋所有者へのヒアリング調査概要

\begin{tabular}{|c|c|c|c|}
\hline & $\begin{array}{c}\text { 接道不良 } \\
\text { 長屋所有者 }\end{array}$ & 接道長屋所有者 & 計 \\
\hline 所有者が利用 & 85 人 & 17 人 & 102 人 \\
\hline 所有者以外が利用 & 4 人 & 1 人 & 5 人 \\
\hline 計 & 89 人 & 18 人 & 107 人 \\
\hline
\end{tabular}

表 2 新規流入者に関するヒアリング調查概要

\begin{tabular}{|l|c|c|c|c|c|}
\hline & 独立店舗 & 兼用住居 & 専用住居 & 萌練㥎 & 合計 \\
\hline ヒアリング調査実施数 & 22 & 22 & 8 & 25 & 77 \\
\hline 分析対象物件 & 21 & 16 & 8 & - & 45 \\
\hline
\end{tabular}




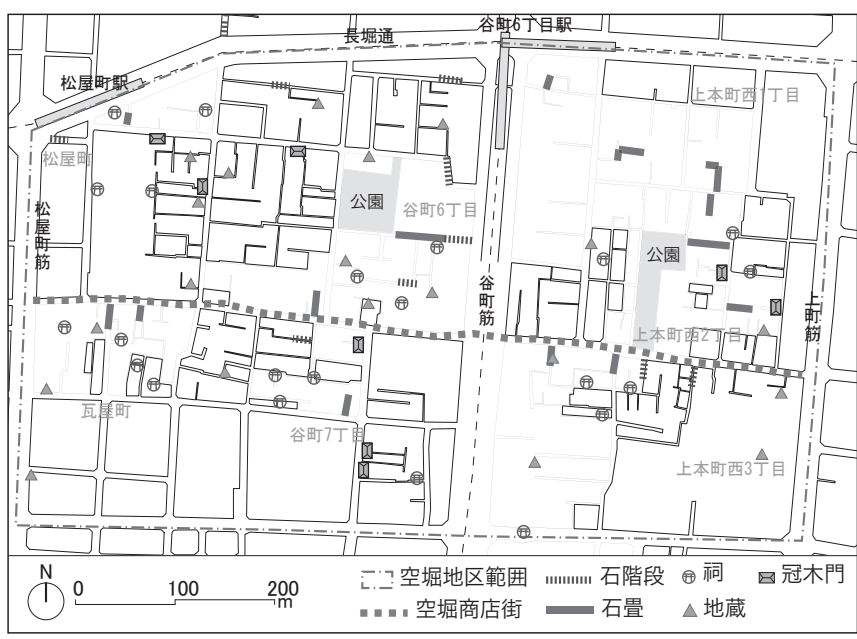

図 2 空堀地区内の地域資源の分布の現状

に伸びる空堀商店街があり、長屋が面する路地沿いには祠や地蔵、 冠木門などが点在し、大都市都心部でありながら歴史的地域資源が 数多く残る地域である注 5 。

その一方で、2004 年度からは地域の魅力を活かしたまちなみ修景 事業である大阪市の「空堀 HOPE ゾーン事業」が地元 HOPE ゾーン協 議会により取り組まれており、これまでにモデル路地の整備など様々 な成果を上げているが、接道不良長屋の居住改善や路地保全につい ては、勉強会などを重初つつも模索している状態にある注6)。

\section{3. 空堀地区の空間特性と路地単位特性}

本章では、空堀地区全体としての空間特性を把握すると共に、図 1 で示した 55 の路地単位ごとの特性の概要把握を行う。

\section{3-1. 空堀地区全体の空間特性}

図 3 は空堀地区内における幅員 $4 \mathrm{~m}$ 未満の路地の分布を表している。 空堀地区内には 2 項道路や通路が数多く分布しており、地区内の道 路・通路を合わせた総延長の内、約 6 割が幅員 $4 \mathrm{~m}$ 未満となっている。

また調查路地ブロック内の接道条件別の長屋の分布を見ると（図 4)、「道路に面する長屋」は $20.8 \%$ 、「接道不良長屋」は $79.2 \%$ となっ ており、全体の約 8 割が接道不良長屋であることがわかる注7。

図 5 は 1989 年から 2009 年までの 20 年間における 5 年ごとの空 堀地区内の高層建築物（6 階以上）の建設状況を表したものである。 ここから、幹線道沿いを中心として高層建築物が継続的に建設され ている状況がわかる。

次に空地と空き家の分布（図 6）を見ると、空地と空き家は地区 全体に点在していることがわかる。また表 3 は未利用地の接道状 況、表 4 は空き家の接道状況を表している。ここから、未利用地の $62.2 \%$ は $4 \mathrm{~m}$ 未満の路地のみに面し、また空き家の $75.5 \%$ は $4 \mathrm{~m}$ 未満 の路地のみに面している。このような状沉からも、特に $4 \mathrm{~m}$ 未満の路 地のみに面する街区内部の未利用地や空き家は対策がとれないまま 放置されている状況が伺われる。

\section{3-2. 路地単位ごとの空間特性の類型化}

空堀地区の路地単位特性を考える上で重要な空間条件として考え られる「(1)地蔵・祠の有無」、「(2)起伏（坂・高低差）の有無」、「(3) 袋小路の有無」の 3 つの視点から 55 の路地単位について類型化を行 い、その結果、表 5 に示す $\mathrm{a}$ 一 h に示寸 8 つの類型タイプにまとめ ることができた。また表 6 に類型タイプごとの 55 の路地単位の空間

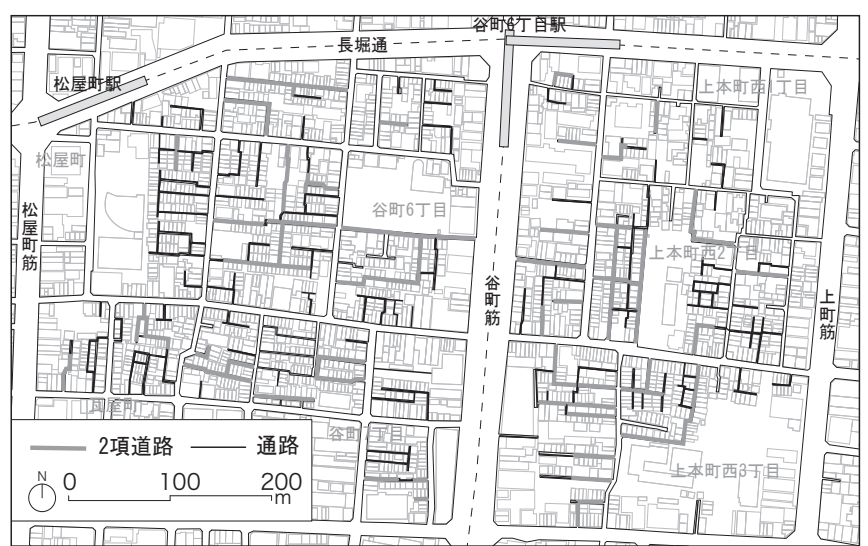

図 3 空堀地区内の幅員 $4 \mathrm{~m}$ 未満の路地の分布

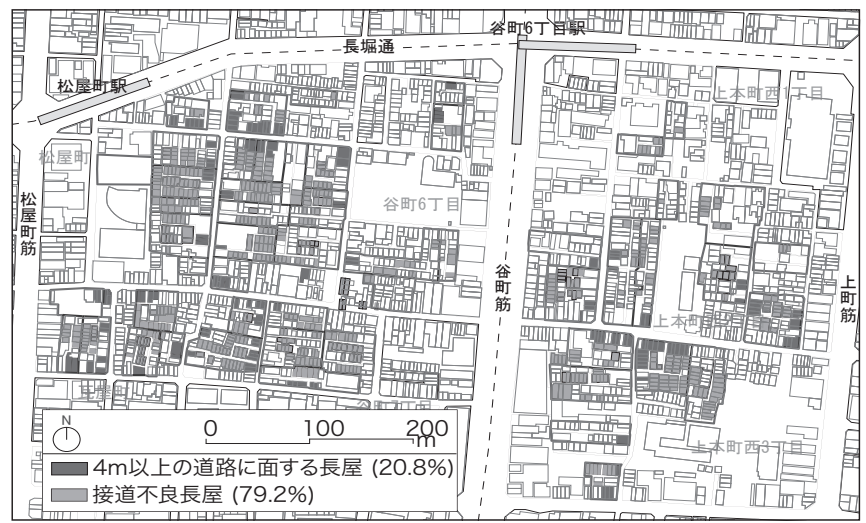

図 4 調查路地単位内の接道条件別の長屋の分布

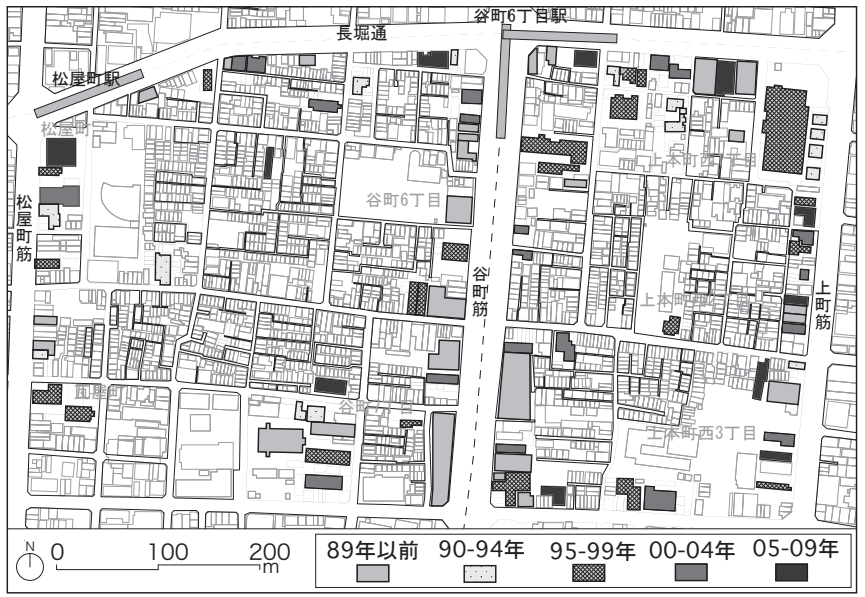

図 5 空堀地区における高層建築物（6 階建以上）の建設状況

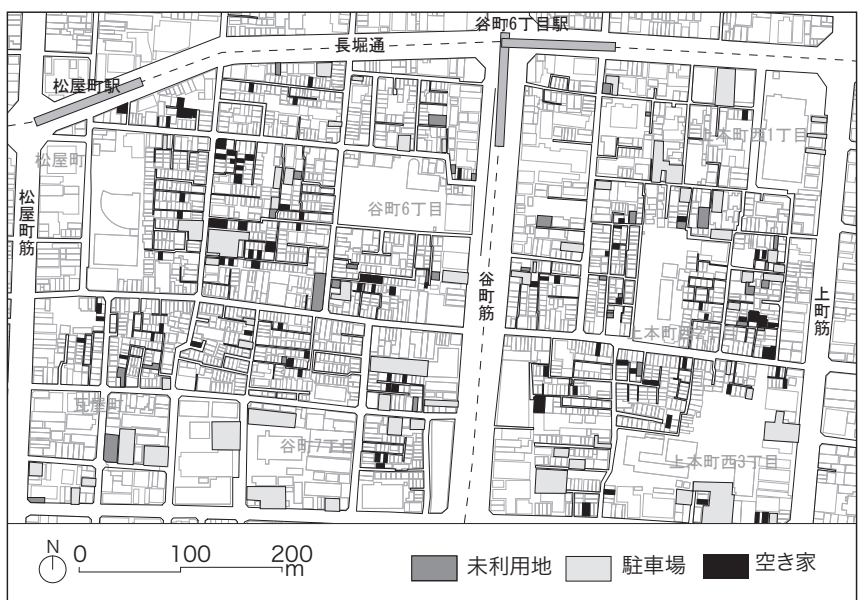

図 6 空堀地区における空地（未利用地・駐車場）と空き家の分布 
表 3 未利用地の接道状況

\begin{tabular}{|c|c|c|c|c|c|c|c|}
\hline \multirow[b]{2}{*}{ 建物種類 } & \multicolumn{3}{|c|}{$4 \mathrm{~m}$ 未満の路地のみに接道 } & \multicolumn{2}{|c|}{$\begin{array}{l}4 \mathrm{~m} \text { 未満の路地 } \\
\text { +道路に接道 }\end{array}$} & \multirow[b]{2}{*}{$\begin{array}{c}\text { 道路のみ } \\
\text { に接道 }\end{array}$} & \multirow[b]{2}{*}{ 合計 } \\
\hline & 通路のみ & 2項道路 & \begin{tabular}{|c|} 
通路+2項 \\
道路
\end{tabular} & $\begin{array}{c}\text { 道路+通 } \\
\text { 路 }\end{array}$ & $\begin{array}{l}\text { 道路+2項 } \\
\text { 道路 }\end{array}$ & & \\
\hline 小計 & 12 & 9 & 2 & 0 & 0 & 14 & 37 \\
\hline 合計 & & & $23(62.2 \%)$ & & & $14(37.8 \%)$ & 37 \\
\hline
\end{tabular}

表 4 空き家の接道状況

\begin{tabular}{|c|c|c|c|c|c|c|c|}
\hline \multirow[b]{2}{*}{ 建物種類 } & \multicolumn{3}{|c|}{$4 \mathrm{~m}$ 未満の路地のみに接道 } & \multicolumn{2}{|c|}{$\begin{array}{c}4 \mathrm{~m} \text { 未満の路地＋道路 } \\
\text { に接道 }\end{array}$} & \multirow{2}{*}{$\begin{array}{c}\text { 道路のみ } \\
\text { に接道 }\end{array}$} & \multirow{2}{*}{ 合計 } \\
\hline & 通路のみ & 2項道路 & \begin{tabular}{|c|} 
通路+2項 \\
道路
\end{tabular} & $\begin{array}{c}\text { 道路+通 } \\
\text { 路 }\end{array}$ & \begin{tabular}{|c|} 
道路+2項 \\
道路
\end{tabular} & & \\
\hline 長屋 & 16 & 17 & 6 & 2 & 0 & 10 & 51 \\
\hline 長屋以外 & 32 & 9 & 0 & 1 & 0 & 14 & 56 \\
\hline 小計 & 48 & 26 & 6 & 3 & 0 & 23 & 106 \\
\hline 合計 & & & $80(75.5 \%)$ & & $3(2.8 \%)$ & $23(21.7 \%)$ & 106 \\
\hline
\end{tabular}

条件の概要を示す。

表 6 を全体的に見ると、(1)一(3)の空間条件の内、2 つ以上が該当 する類型タイプでは個別の地域資源を複数持つものが多いと言え、 特に(1)一(3)全ての空間条件を持つ a タイプ（地蔵又は祠あり／起 伏あり／袋小路あり)では個別の地域資源が多数分布している。なお、 表 5 に示す「路地単位内の平均長屋数」を見ると、同じく(1)一(3)の 空間条件が 3 つも揃っている a タイプが 19.1 戸と最も多く、これ らの 3 つの空間条件は長屋をはじめ、地域資源の保全に繋がる要因 であると考えられる。

また、「(2)起伏」の無いc、d、g、h の路地単位の中には、接道不 良長屋の割合が $0 \%$ となっている路地単位が複数見られ、これらは 起伏のある路地単位に比べて建物更新が容易であること示しており、 長屋の取り壊しによる駐車場化やミニ戸建住宅、高層マンションな どに変化しているものもある。

\section{3-3. 路地単位ごとの空間特性とコミュニティ活動との関係}

次に路地単位ごとの空間特性とコミュニティ活動との関係を考察 するため、各類型タイプの中でも特に地形条件や個別の地域資源の 分布に特徴を持つ 20 の路地単位を抽出した注9)。そして表 7 に 20 の 路地単位の類型タイプごとの「以前と現在のコミュニティ活動の状 況」を日常と非日常に分けて示し、以下考察を行っていく注10)。

（1）現在は行われていないコミュニティ活動

「以前あったが現在は行われていないコミュニティ活動」の主なも のとして、日常では「井戸端会議」、非日常では「日帰り旅行」、「冠 婚葬祭の手伝い、「食事会」「入院時のお見舞い」等となっている。 このような背景としてヒアリングによると、近年の居住者の高齢化 や子供の減少、物騒になり玄関の扉を閉めるようになったこと、外 で仕事をする人が増えたこと、冠婚葬祭は自宅ではなく集会所や会 館でするようになったことなど、社会的な要因が多く影響している。 また路地単位内での空間的な環境の変化もコミュニティ活動の減少 の大きな要因であると言え、例えばNo. 23 の路地単位では借地が多 く、高層マンション建設に向けた立ち退き地区になっているため、 高齢者が多く空き家や空き地が増え、個人的な交流はあっても、路 地単位内での行事的な活動は減少しているという。

（2）現在も行われているコミュニティ活動

一方で「現在も行われているコミュニティ活動」の主なものとし ては、日常では「祠の共同管理」、「地蔵の共同管理」、「路地の共同 清掃」、非日常では「お稲荷さんの祭り」、地蔵盆」などとなっている。 なお、類型別のコミュニティ活動の状況を全体的に見ると、「(1)地
表 5 路地単位特性の類型結果

\begin{tabular}{|c|c|c|c|c|c|}
\hline \multicolumn{3}{|c|}{ 空間条件 } & $\begin{array}{l}\text { 類型 } \\
\text { タイプ }\end{array}$ & 類型の該当数 & $\begin{array}{c}\text { 路地単位内の } \\
\text { 平均長屋数 }\end{array}$ \\
\hline \multirow{4}{*}{$\begin{array}{c}\text { (1)地蔵又は祠 } \\
\text { あり }\end{array}$} & \multirow{2}{*}{ (2)起伏あり } & (3)袋小路あり & $a$ & $7(12.7 \%)$ & 19.1 \\
\hline & & (3)袋小路なし & $\mathrm{b}$ & $4(7.3 \%)$ & 9.6 \\
\hline & \multirow{2}{*}{ (2)起伏なし } & (3)袋小路あり & c & $12(21.8 \%)$ & 17.3 \\
\hline & & (3)袋小路なし & d & $2(3.6 \%)$ & 16 \\
\hline \multirow{4}{*}{$\begin{array}{c}\text { (1)地蔵又は祠 } \\
\text { よし }\end{array}$} & \multirow{2}{*}{ (2)起伏あり } & (3)袋小路あり & $\mathrm{e}$ & $7(12.7 \%)$ & 15.3 \\
\hline & & (3)袋小路なし & $f$ & $4(7.3 \%)$ & 8.4 \\
\hline & \multirow{2}{*}{ (2)起伏なし } & (3)袋小路あり & $\mathrm{g}$ & $9(16.4 \%)$ & 9.9 \\
\hline & & (3)袋小路なし & h & $10(18.2 \%)$ & 10.4 \\
\hline
\end{tabular}

表 6 路地単位ごとの空間特性の概要注 8$)$

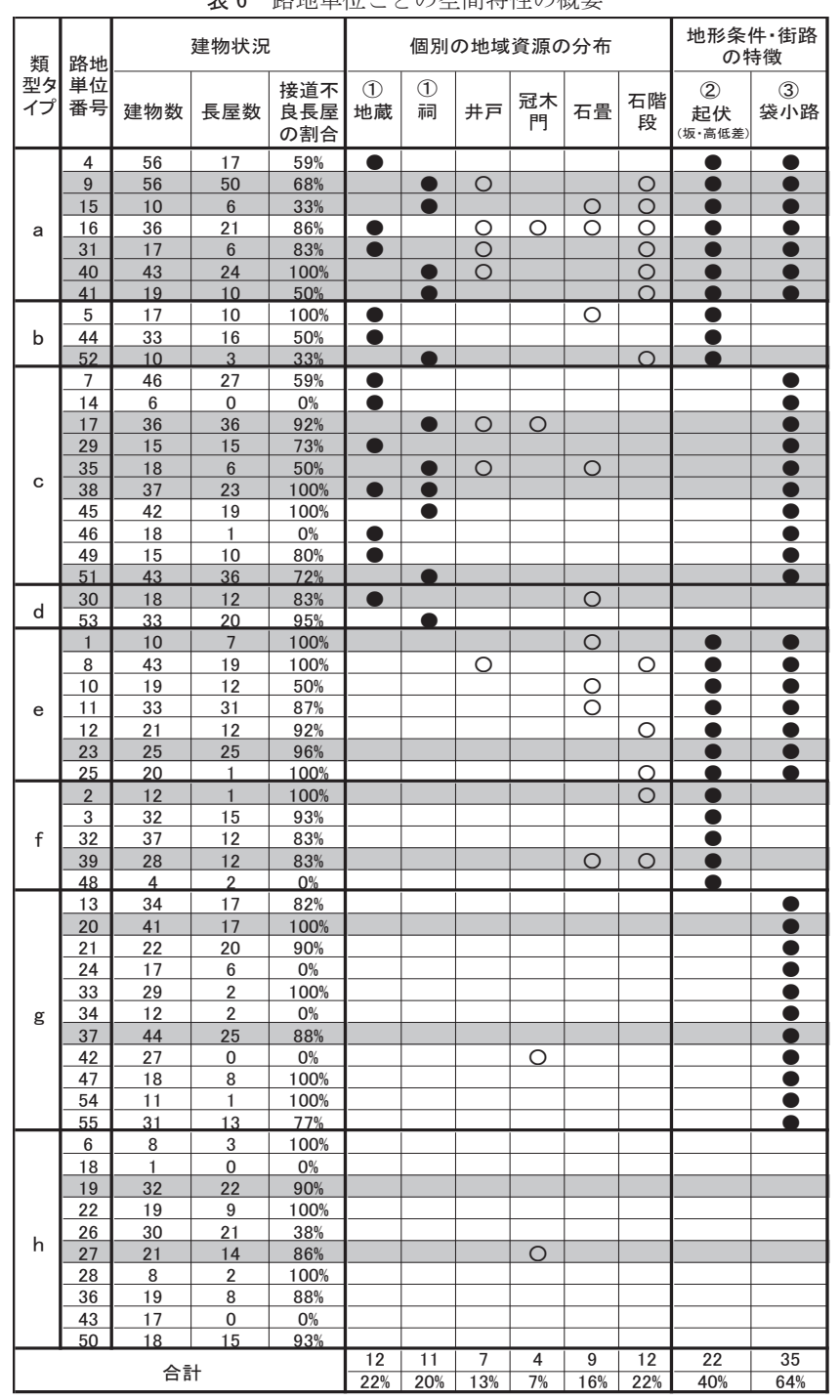

※網掛けしている路地単位は 3 章 3-3. で対象にしている 20 の路地単位。 ※「接道不良長屋の割合」とは、「長屋数」を母数とした接道不良長屋の割合 を示している。

蔵又は祠の有無」で大きな差異が見られ、地蔵又は祠を持つ a $~ d ~ d ~$ の路地単位では以前と現在共にコミュニティ活動が多く見られる。

以上のことからも、全体的に現在は行われていない活動も多いが、 祠や地蔵の存在が、現在でも路地単位内でのコミュニティ活動を継 続させている重要な資源であるといえる。

\section{（3）新しく出来たコミュニティ活動}

さらに以前は無かったが現在行われている「新しく出来たコミュ ニティ活動」として、表 8 に挙げるような活動が見られる。特に No. 1 と No. 19 の路地単位では地蔵や祠を持たない路地単位であるが、 新規流入者の存在が地区内での新たな交流を生み出し、防災や高齢 者福祉の面においても重要な役割を果たしつつあるといえる。 
表 7 以前と現在の路地単位ごとのコミュニティ活動状況

(上段○：以前行われていた活動、下段○：現在行われている活動)

\begin{tabular}{|c|c|c|c|c|c|c|c|c|c|c|c|c|c|}
\hline \multirow{2}{*}{\multicolumn{2}{|c|}{ 類型タイプ }} & \multirow{2}{*}{\multicolumn{2}{|c|}{\begin{tabular}{|} 
路地 \\
単位 \\
番号
\end{tabular}}} & \multicolumn{4}{|c|}{ 日常 } & \multicolumn{6}{|c|}{ 非日常 } \\
\hline & & & & $\begin{array}{l}\text { 祠(稲 } \\
\text { 荷)の } \\
\text { 共同 } \\
\text { 管理 }\end{array}$ & $\begin{array}{l}\text { 地藏 } \\
\text { の共 } \\
\text { 同管 } \\
\text { 理 }\end{array}$ & $\begin{array}{l}\text { 路地 } \\
\text { の共 } \\
\text { 同清 } \\
\text { 掃 }\end{array}$ & $\begin{array}{l}\text { 井戸 } \\
\text { 端会 } \\
\text { 議 }\end{array}$ & $\begin{array}{l}\text { お稲荷 } \\
\text { さんの } \\
\text { 祭り }\end{array}$ & $\begin{array}{c}\text { 地蔵 } \\
\text { 盈 }\end{array}$ & $\begin{array}{l}\text { 冠婚 } \\
\text { 葬祭 } \\
\text { の手 } \\
\text { 伝い }\end{array}$ & \begin{tabular}{|c|} 
入院 \\
時のお \\
見舞い
\end{tabular} & $\begin{array}{c}\text { 食事 } \\
\text { 会 }\end{array}$ & $\begin{array}{l}\text { 日州り } \\
\text { 旅行 }\end{array}$ \\
\hline & \multirow{6}{*}{$\begin{array}{l}\text { (3)袋小 } \\
\text { 路あり }\end{array}$} & & 9 & 0 & - & 0 & & 0 & - & - & & & \\
\hline \multirow{13}{*}{$\begin{array}{l} \\
\\
11 \\
\text { 地 } \\
\text { 蔵 } \\
\text { 又 } \\
\text { は } \\
\text { 祠 } \\
\text { あ } \\
\text { り }\end{array}$} & & & 15 & $\frac{1}{0}$ & - & $\begin{array}{l}0 \\
0\end{array}$ & 0 & 0 & - & 0 & & 0 & \\
\hline & & & 31 & - & 0 & & & - & 0 & & & & \\
\hline & & & 31 & & 0 & & & & 0 & & & & \\
\hline & & & 40 & 0 & - & & & & - & & & & \\
\hline & & & 41 & 0 & - & & & $\frac{1}{0}$ & - & 0 & & 0 & \\
\hline & $\begin{array}{l}\text { 3袋小 } \\
\text { 路なしし }\end{array}$ & $b$ & 52 & 0 & - & & & 0 & & & & & \\
\hline & \multirow{6}{*}{$\begin{array}{l}\text { (3)袋小 } \\
\text { 路あり }\end{array}$} & \multirow{6}{*}{ c } & 17 & 0 & - & $\begin{array}{l}0 \\
0\end{array}$ & 0 & 0 & - & 0 & 0 & 0 & 0 \\
\hline & & & 29 & - & 0 & & & - & 0 & 0 & & & \\
\hline & & & 35 & 0 & - & & & 0 & - & & & & 0 \\
\hline & & & 38 & 0 & 0 & & & 0 & 0 & 0 & & 0 & \\
\hline & & & & 0 & 0 & & & 0 & 0 & & & & \\
\hline & & & 51 & 0 & - & & & - & - & & & & \\
\hline & $\begin{array}{l}\text { 3垡小 } \\
\text { 路なしし }\end{array}$ & d & 30 & - & 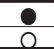 & - & & - & 0 & & 0 & & \\
\hline \multirow{8}{*}{$\begin{array}{l}\text { 崩 } \\
\text { 方 } \\
\text { な } \\
\text { L }\end{array}$} & \multirow{2}{*}{\begin{tabular}{|l} 
3)袋小 \\
路あり
\end{tabular}} & \multirow{2}{*}{$\mathrm{e}$} & 1 & - & - & & & - & - & - & & 8 & \\
\hline & & & 23 & - & - & & & - & - & 0 & & & 0 \\
\hline & \multirow{2}{*}{$\begin{array}{l}\text { 3)袋小 } \\
\text { 路なしし }\end{array}$} & \multirow[b]{2}{*}{$f$} & 2 & - & - & & & - & - & & & & \\
\hline & & & 39 & - & - & 0 & & - & - & 0 & & & \\
\hline & \multirow{2}{*}{$\begin{array}{l}\text { 3)袋小 } \\
\text { 路あり }\end{array}$} & \multirow[b]{2}{*}{$\mathrm{g}$} & 20 & - & - & & & - & - & & & & \\
\hline & & & 37 & - & - & & & - & - & & & & \\
\hline & \multirow{2}{*}{$\begin{array}{l}\text { 3)袋小 } \\
\text { 路なよし }\end{array}$} & \multirow[b]{2}{*}{$\mathrm{h}$} & 19 & - & - & & & - & - & 0 & 0 & 0 & 0 \\
\hline & & & 27 & - & - & & & - & - & 0 & 0 & $\bullet$ & \\
\hline \multicolumn{4}{|c|}{$\begin{array}{c}\text { 現在は行われていない } \\
\text { 割合 } \\
\end{array}$} & \begin{tabular}{|c|}
$1 / 8$ \\
$12.5 \%$
\end{tabular} & $\begin{array}{l}0 / 4 \\
0.0 \%\end{array}$ & $\begin{array}{c}2 / 5 \\
40.0 \%\end{array}$ & \begin{tabular}{|l|}
$2 / 2$ \\
$100.0 \%$
\end{tabular} & $\begin{array}{ll}0 / 6 \\
0.0 \%\end{array}$ & $\begin{array}{l}0 / 4 \\
0.0 \% \\
\end{array}$ & $\begin{array}{l}8 / 11 \\
72.7 \%\end{array}$ & $\begin{array}{c}2 / 4 \\
50.0 \%\end{array}$ & $\begin{array}{c}3 / 5 \\
60.0 \%\end{array}$ & $\begin{array}{c}4 / 4 \\
100.0 \%\end{array}$ \\
\hline \multicolumn{4}{|c|}{ 現在も行われている割合 } & \begin{tabular}{|c|}
$7 / 8$ \\
$87.5 \%$ \\
\end{tabular} & $\begin{array}{c}4 / 4 \\
100.0 \% \\
\end{array}$ & $\begin{array}{r}3 / 5 \\
60.0 \% \\
\end{array}$ & $\begin{array}{l}0 / 2 \\
0.0 \%\end{array}$ & \begin{tabular}{|c|}
$6 / 6$ \\
$100.0 \%$ \\
\end{tabular} & \begin{tabular}{|c|}
$4 / 4$ \\
$100.0 \%$ \\
\end{tabular} & $\begin{array}{l}3 / 11 \\
27.3 \% \\
\end{array}$ & $\begin{array}{r}2 / 4 \\
50.0 \% \\
\end{array}$ & $\begin{array}{r}2 / 5 \\
40.0 \% \\
\end{array}$ & $\begin{array}{l}0 / 4 \\
0.0 \% \\
\end{array}$ \\
\hline \multicolumn{14}{|c|}{ 表 8 新しくできたコミュニティ活動 } \\
\hline $\begin{array}{l}\text { 路地 } \\
\text { 単位 }\end{array}$ & \multicolumn{4}{|c|}{ 活動テーマ } & \multicolumn{9}{|c|}{ 活動内容の概要 } \\
\hline $\begin{array}{c}1 \\
\left(e_{\text {タタイフ }}\right)\end{array}$ & 路地て & Eのノ & バーへ & ゙゙キュー & & $\begin{array}{l}\text { 見流入 } \\
\text { ヤラリ- }\end{array}$ & $\begin{array}{l}\text { 複数 } \sigma \\
\text { 経営者 }\end{array}$ & $\begin{array}{l}\text { D賃貸者 } \\
\text { ）を交え }\end{array}$ & $\begin{array}{l}\text { 首(多くか } \\
\text { えての交 }\end{array}$ & 流会。 & =ィスト & による & 大家 \\
\hline $\begin{array}{c}19 \\
\left(h_{\text {タイプ }}\right)\end{array}$ & 新規房 & 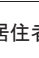 & 者歓之 & 印会 & & $\begin{array}{l}\text { 見居住 } \\
\text { =一致) }\end{array}$ & $\begin{array}{l}\text { 党歓迎 } \\
\text { D複数 }\end{array}$ & $\begin{array}{l}\text { 乣地域 } \\
\text { の既存住 }\end{array}$ & $\begin{array}{l}\text { に溶けが } \\
\text { 济人 }\end{array}$ & $\begin{array}{l}\text { 入̄むよ } \\
\text { 画。 }\end{array}$ & うに、同 & 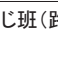 & 地単 \\
\hline $\begin{array}{c}38 \\
(\text { Cタタフ })\end{array}$ & $\begin{array}{l}\text { 防災マ } \\
\text { 者の萛 }\end{array}$ & マップ & $\begin{array}{l}\text { b゚づく } \\
\text { り }\end{array}$ & ノと高齡 & & $\begin{array}{l}\text { 㛄の班 } \\
\text { D比較白 } \\
\text { の日它 } \\
\text { つどの高 }\end{array}$ & $\begin{array}{l}\text { 路地単 } \\
\text { 若い世 } \\
\text { 的な見 } \\
\text { 齢者を }\end{array}$ & $\begin{array}{l}\text { 位と一至 } \\
\text { 代の居 } \\
\text { 守りと } \\
\text { :助けに }\end{array}$ & $\begin{array}{l}\text { 致) の居 } \\
\text { 居住者力 } \\
\text { 共に、防 } \\
\text { 行くのた }\end{array}$ & $\begin{array}{l}\text { 住者に } \\
\text { 中心に } \\
\text { 災時| } \\
\text { をを示し }\end{array}$ & $\begin{array}{l}\text { よる企 } \\
\text { =なって } \\
\text { =備えて } \\
\text { たたマッ }\end{array}$ & $\begin{array}{l}\text { 画。新夫 } \\
\text { 活動。 } \\
\text { 路地 } \\
\text { プつくくり }\end{array}$ & \\
\hline
\end{tabular}

\section{4. 接道不良長屋所有者と所有長屋の概要}

次にここから接道不良長屋所有者の居住改善実態を把握するため、 まず接道不良長屋所有者 85 人と所有長屋 99 戸の概要把握を行う。

\section{4-1. 接道不良長屋所有者の概要}

表 9 に接道不良長屋所有者の年齢と職業を示寸。年齢構成では、 70 代が $32.9 \%$ と最も高く、次いで 60 代が $24.7 \%$ であなど、全体 の 8 割が 60 代以上となっている。また長屋所有者の職業では、無職 が 46 人 (54.1\%) と最も多く、次いで自営業者が 27 人 (31. 8\%) となっており、特に 60 代以上で自営業を営んでいる世帯が 27 人中 21 人 $(77.8 \%)$ と多いことが特徴的である。

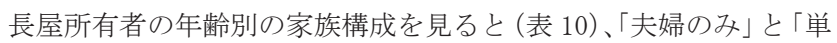
身」が約 3 割、「夫婦十子」が約 2 割でその大半が 60 代以上であり、 高齢世帯が多い様子が伺われる。

また長屋所有者の年齢別の入居時期を見ると（表 11）、1940 年代 に入居し始めた世帯が圧倒的に多いが、2000 年代以降の入居に増加
傾向が見られ、30 代や 40 代など比較的若い世帯の入居が目立つ。

\section{4-2. 接道不良長屋の建築時期と接道状況}

調査世帯が所有する接道不良長屋の建築時期では（表 12）、「不明」 の 34 戸を除く 65 戸の内、明治以前が 41 戸 $(63.1 \%)$ 、大正一第 2 次世界大戦中が 22 戸 $(33.9 \%)$ で、大半が戦前に建設されている。 また接道不良長屋の接道状況では（表 14）、99 戸の内、通路のみに 面する長屋は 57 戸 $(57.6 \%) 、 2$ 項道路のみは 34 戸 $(34.3 \%) 、$ 通 路と 2 項道路の両方は 8 戸 $(8.1 \%)$ となっている。

\section{5. 接道不良長屋所有者の居住改善実態}

\section{5-1. 居住改善手法の類型化}

接道不良長屋の保全的更新を考える上では特に、住戸規模の拡大 や外観上の変化を伴う居住改善が重要になると考えられる。そこで ここでは、設備の向上や内装の改修など住戸の規模や外観に変化の 無い軽微な改善手法を除いて、接道不良長屋所有世帯の居住改善手 法について類型化を行ない（図 7)、その結果、以下の A - E の 5 つ の改善手法に整理することができた。なお表 14 に改善手法ごとの組 み合わせを示しているが、 5 つの改善手法は 1 つの世帯においても 複数組み合わされる場合があり、一方軽微な改善や改善を行ってい

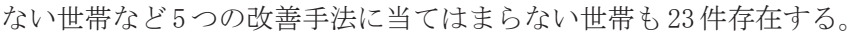

「A. 駆体の一部を残した全面的増改築タイプ」(35 世帯/85 世帯、 41. $2 \%$ ）: 建て替えという位置づけにしないために、前面道路に面寸 る部分や柱など駆体の一部を残し全面的増改築を行っているタイプ。 「B. 複数戸利用タイプ」(16 世帯 /85 世帯、18.8\%) : 空堀地区内に

表 9 接道不良長屋所有者の年齢と職業 $(\mathrm{n}=85)$

\begin{tabular}{|c|c|c|c|c|c|}
\hline & その他 & 会社員 & 自営業 & 無職 & 合計 \\
\hline 30 代 & 1 & 1 & 1 & 0 & $3(3.5 \%)$ \\
\hline 40 代 & 0 & 1 & 4 & 1 & $6(7.1 \%)$ \\
\hline 50 代 & 1 & 2 & 1 & 4 & $8(9.4 \%)$ \\
\hline 60 代 & 0 & 2 & 11 & 8 & $21(24.7 \%)$ \\
\hline 70 代 & 0 & 1 & 8 & 19 & $28(32.9 \%)$ \\
\hline 80 代以上 & 2 & 0 & 2 & 15 & $19(22.4 \%)$ \\
\hline 合計 & $4(4.7 \%)$ & $7(8.2 \%)$ & $27(31.8 \%)$ & $46(54.1 \%)$ & $85(100.0 \%)$ \\
\hline
\end{tabular}

表 10 接道不良長屋所有者の年齢別の家族構成 $(\mathrm{n}=85)$

\begin{tabular}{|c|c|c|c|c|c|c|c|}
\hline & 単身 & 夫婦のみ & 夫婦+子 & 3世代 & その他 & 無回答 & 合計 \\
\hline 30 代 & 0 & 1 & 2 & 0 & 0 & 0 & $3(3.5 \%)$ \\
\hline 40 代 & 2 & 2 & 1 & 0 & 0 & 1 & $6(7.1 \%)$ \\
\hline 50 代 & 1 & 0 & 5 & 0 & 1 & 1 & $8(9.4 \%)$ \\
\hline 60 代 & 6 & 6 & 6 & 1 & 0 & 2 & $21(24.7 \%)$ \\
\hline 70 代 & 3 & 15 & 4 & 1 & 4 & 1 & $28(32.9 \%)$ \\
\hline 80代以上 & 11 & 4 & 0 & 1 & 1 & 2 & $19(22.4 \%)$ \\
\hline 合計 & $23(27.1 \%)$ & $28(32.9 \%)$ & $18(21.2 \%)$ & $3(3.5 \%)$ & $6(7.1 \%)$ & $7(8.2 \%)$ & $85(100.0 \%)$ \\
\hline
\end{tabular}

表 11 接道不良長屋所有者の年齢別の入居時期 $(\mathrm{n}=85)$

\begin{tabular}{|c|c|c|c|c|c|c|c|c|c|}
\hline & $\begin{array}{c}1920 \\
\text { 年代 }\end{array}$ & $\begin{array}{c}1930 \\
\text { 年代 }\end{array}$ & $\begin{array}{c}1940 \\
\text { 年代 }\end{array}$ & $\begin{array}{c}1950 \\
\text { 年代 }\end{array}$ & $\begin{array}{c}1960 \\
\text { 年代 }\end{array}$ & $\begin{array}{c}1970 \\
\text { 年代 }\end{array}$ & $\begin{array}{c}1980 \\
\text { 年代 }\end{array}$ & $\begin{array}{c}1990 \\
\text { 年代 }\end{array}$ & $\begin{array}{c}2000 \\
\text { 年代 }\end{array}$ \\
\hline 30 代 & & & & & & & & & 3 \\
\hline 40 代 & & & & & 2 & & 2 & & 2 \\
\hline 50 代 & & & & 3 & & 1 & 1 & 2 & 1 \\
\hline 60 代 & & & 6 & 4 & 2 & 3 & 4 & & 2 \\
\hline 70 代 & 1 & 5 & 10 & 3 & 3 & 2 & 1 & 2 & 1 \\
\hline 80 代以上 & 3 & 1 & 11 & 2 & & & 2 & & \\
\hline \multirow{2}{*}{ 合計 } & 4 & 6 & 27 & 12 & 7 & 6 & 10 & 4 & 9 \\
\cline { 2 - 11 } & $4.7 \%$ & $7.6 \%$ & $31.8 \%$ & $14.1 \%$ & $8.2 \%$ & $7.1 \%$ & $11.8 \%$ & $4.7 \%$ & $10.6 \%$ \\
\hline
\end{tabular}

表 12 接道不良長屋の建設時期 $(\mathrm{n}=99)$

\begin{tabular}{|c|c|c|c|c|}
\hline 明治以前 & $\begin{array}{c}\text { 大正〜第2次 } \\
\text { 世界大戦單 }\end{array}$ & 後すぐ & 不明 & 合計 \\
\hline 41 & 22 & 2 & 34 & 99 \\
\hline
\end{tabular}

表 13 ヒアリング調査長屋の接道状況 $(\mathrm{n}=99)$

\begin{tabular}{|c|c|c|}
\hline 通路のみ & 2項道路のみ & 両方（通路+2項道路） \\
\hline $57(57.6 \%)$ & $34(34.3 \%)$ & $8(8.1 \%)$ \\
\hline
\end{tabular}


おいて、建物どうしが住戸内部で 連結しない複数の建物を利用し、そ の内の 1 つ以上が接道不良の長屋 であるタイプ。

「C. n戸 1 化タイプ」(14 世帯 / 85 世 帯、16.5\%)：隣接する長屋を増改 築によって統合・連結又は分割し ているタイプ。

「D. 2 - 3 階の増築タイプ」(8 世帯 $/ 85$ 世帯、9.4\%) : 平屋や 2 階だっ た長屋を増築によって 2 階又は 3 階建にしているタイプ。

「E. 拡張又は別棟による増築タイプ」（7 世帯 /85 世帯、8.2\%）：既 存建物を拡張する形での増築や別棟での増築を行なっているタイプ。

\section{5-2. 類型別の居住改善実態}

類型別の居住改善の動機を表 15、類型別の長屋の利用内容を表 16 に示す。全体的傾向を見ると、居住改善の動機（表 15）では「老朽 化一の対応」(53.8\%)、「設備の向上」(51.3\%)、「狭さの解消」(50.0\%) が多く、利用用途（表 16）では「住居専用」が $72.7 \%$ と圧倒的に多 いが、兼用住宅、倉庫、店舗、工場などの住居以外の利用も見られる。 以下、類型ごとに居住改善の動機と利用内容を見ていく。

\section{（1）「A．駆体の一部を残した全面的増改築タイプ」}

「A. 駆体の一部を残した全面的増改築タイプ」では、「老朽化への 対応」「設備の向上」の割合が圧倒的に高い一方で、特に「耐震性の 向上」「防災の向上」「防犯の向上」「修景」「バリアフリー」など、 他のタイプではほとんど見られない動機が複数該当していることが 特徴的である。また、このタイプの利用内容は専用住居や兼用住居 など住居系に利用されており、様々な用途の兼用住居が見られる。

\section{（2）「B．複数戸利用タイプ」}

「B. 複数戸利用タイプ」では、家族の成長や独立に伴う「近居」や、 「機能の追加・変更」が他のタイプに比べ高い。利用用途を見ると、 住居以外の単独の用途に使われている割合が高いことが特徵である と言え、これは複数の長屋を所有してることを活かし、1つは住居、 もう 1 つは店舗や工場としての利用するなど建物ごとに利用用途を 変えているためであると考えられる。また表 17 は、「B. 複数戸利用 タイプ」の建物じうしの位置関係を表している。ここから、16 件の内、 隣接が 2 件 $(12.5 \%)$ 、向こう 3 軒が 7 件 $(43.8 \%)$ 、同じ路地単位 内が 6 件 $(37.5 \%)$ であり、ほとんどの世帯がごく近い位置関係で 複数の長屋を利用していることが分かった。

(3)「C.n戸1化タイプ」

「C.n戸 1 化タイプ」では、「狭さの解消」が $92.9 \%$ と圧倒的に高く、 次いで「家族構成の変化」と「機能の追加」が $28.6 \%$ となっている。

利用用途を見るとこのタイプでは、 2 戸 1 で専用住居として利用 するだけでなく、2戸1の片方を住居、もう片方を工場やその他の 用途として利用している世帯が複数見られることが特徵である。

\section{（4）「D. $2 \cdot 3$ 階の増築タイプ」}

「D. $2 \cdot 3$ 階の増築タイプ」では、「狭さの解消」や「家族構成の変化 が主な動機となっている。利用用途を見ると、このタイプでは全て が住居系の利用であることが特徵で、中には増築した 3 階部分をア トリエとして利用するなどの事例も見られる。

\section{(5)「E．拡張又は別棟による増築タイプ」}

「E. 拡張又は別棟による増築タイプ」では、「狭さの解消」（7 件

\begin{tabular}{|l|l|l|}
$\begin{array}{l}\text { C. n戸1化タイプ } \\
(14 / 85 \text { 世帯、16.5\%) }\end{array}$ & $\begin{array}{l}\text { D. 2-3階の増築タイプ } \\
(8 / 85 \text { 世帯、9.4\% })\end{array}$ & $\begin{array}{l}\text { E. 应張又は别棟による増築 } \\
\text { タイプ(7/85世帯、8.2\% })\end{array}$ \\
\hline
\end{tabular}

図 7 増改築など居住改善手法の $5 つ$ ๖イプ

表 14 調査世帯における改善手法タイプの組み合わせ

\begin{tabular}{|c|c|c|c|c|c|c|c|c|c|c|c|c|}
\hline $\begin{array}{c}\mathrm{A} の \\
\text { み }\end{array}$ & $\begin{array}{c}\mathrm{B} の \\
\text { み }\end{array}$ & $\begin{array}{c}\mathrm{Cの} \\
\text { み }\end{array}$ & $\begin{array}{c}\text { Dの } \\
\text { み }\end{array}$ & $\begin{array}{c}E の \\
\text { み }\end{array}$ & $A+B$ & $A+C$ & $\mathrm{~A}+$ & B & & $D+E$ & $\begin{array}{l}\text { 該当 } \\
\text { なし }\end{array}$ & 合計 \\
\hline 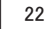 & 6 & 9 & 2 & 4 & 7 & 5 & 4 & & & 2 & 23 & 85 \\
\hline
\end{tabular}

表 15 類型別の増改築など居住改善の動機 $(\mathrm{n}=80)$

\begin{tabular}{|c|c|c|c|c|c|c|c|}
\hline & & $\begin{array}{l}\text { A.駆体の } \\
\text { 一部を残 } \\
\text { した全面 } \\
\text { 的増改築 }\end{array}$ & $\begin{array}{l}\text { B.複数戸 } \\
\text { 利用 }\end{array}$ & C.n戸1化 & $\begin{array}{l}\text { D.2.3階 } \\
\text { の増築 }\end{array}$ & $\begin{array}{l}\text { E.拡張又 } \\
\text { は別棟に } \\
\text { よる増築 }\end{array}$ & 合計 \\
\hline \multirow{14}{*}{$\begin{array}{l}\text { 空 } \\
\text { 間 } \\
\text { に } \\
\text { よ } \\
\text { る } \\
\text { 動 } \\
\text { 機 }\end{array}$} & \multirow{2}{*}{ 老朽化への対応 } & $30 / 35$ & $4 / 16$ & $5 / 14$ & $1 / 8$ & $3 / 7$ & $43 / 80$ \\
\hline & & $85.7 \%$ & $25.0 \%$ & $35.7 \%$ & $12.5 \%$ & $42.9 \%$ & $53.8 \%$ \\
\hline & \multirow{2}{*}{ 狭さの解消 } & $10 / 35$ & $5 / 16$ & $13 / 14$ & $5 / 8$ & $7 / 7$ & $40 / 80$ \\
\hline & & $28.6 \%$ & $31.3 \%$ & $92.9 \%$ & $62.5 \%$ & $100.0 \%$ & $50.0 \%$ \\
\hline & \multirow{2}{*}{ 耐震性の向上 } & $7 / 35$ & $0 / 16$ & $1 / 14$ & $0 / 8$ & $0 / 7$ & $8 / 80$ \\
\hline & & $20.0 \%$ & $0.0 \%$ & $7.1 \%$ & $0.0 \%$ & $0.0 \%$ & $10.0 \%$ \\
\hline & \multirow{2}{*}{ 防災の向上 } & $6 / 35$ & $0 / 16$ & $0 / 14$ & $0 / 8$ & $0 / 7$ & $6 / 80$ \\
\hline & & $17.1 \%$ & $0.0 \%$ & $0.0 \%$ & $0.0 \%$ & $0.0 \%$ & $7.5 \%$ \\
\hline & \multirow{2}{*}{ 防犯の向上 } & $3 / 35$ & $0 / 16$ & $1 / 14$ & $0 / 8$ & $0 / 7$ & $4 / 80$ \\
\hline & & $8.6 \%$ & $0.0 \%$ & $7.1 \%$ & $0.0 \%$ & $0.0 \%$ & $5.0 \%$ \\
\hline & \multirow{2}{*}{ 設備の向上 } & $30 / 35$ & $4 / 16$ & $2 / 14$ & $1 / 8$ & $4 / 7$ & $41 / 80$ \\
\hline & & $85.7 \%$ & $25.0 \%$ & $14.3 \%$ & $12.5 \%$ & $5.7 \%$ & $51.3 \%$ \\
\hline & \multirow{2}{*}{ 修景 } & $2 / 35$ & $0 / 16$ & $0 / 14$ & $0 / 8$ & $0 / 7$ & $2 / 80$ \\
\hline & & $5.7 \%$ & $0.0 \%$ & $0.0 \%$ & $0.0 \%$ & $0.0 \%$ & $2.5 \%$ \\
\hline \multirow{8}{*}{$\begin{array}{c}\text { 居 } \\
\text { 住 } \\
\text { 者 } \\
\text { に } \\
\text { よ } \\
\text { る } \\
\text { 動 } \\
\text { 機 }\end{array}$} & \multirow{2}{*}{ 家族構成の変化 } & $6 / 35$ & $0 / 16$ & $4 / 14$ & $4 / 8$ & $5 / 7$ & $19 / 80$ \\
\hline & & $17.1 \%$ & $0.0 \%$ & $28.6 \%$ & $50.0 \%$ & $71.4 \%$ & $23.8 \%$ \\
\hline & \multirow{2}{*}{$\begin{array}{l}\text { 家族の成長や独 } \\
\text { 立に伴う近居 }\end{array}$} & $0 / 35$ & $9 / 16$ & $0 / 14$ & $0 / 8$ & $0 / 7$ & $9 / 80$ \\
\hline & & $0.0 \%$ & $56.3 \%$ & $0.0 \%$ & $0.0 \%$ & $0.0 \%$ & $11.3 \%$ \\
\hline & \multirow{2}{*}{ バリアフリー } & $8 / 35$ & $0 / 16$ & $0 / 14$ & $0 / 8$ & $1 / 7$ & $9 / 80$ \\
\hline & & $22.9 \%$ & $0.0 \%$ & $0.0 \%$ & $0.0 \%$ & $14.3 \%$ & $11.3 \%$ \\
\hline & \multirow{2}{*}{\begin{tabular}{|l}
$\begin{array}{l}\text { 機能の追加·変 } \\
\text { 更 }\end{array}$ \\
\end{tabular}} & $6 / 35$ & $8 / 16$ & $4 / 14$ & $1 / 8$ & $1 / 7$ & $20 / 80$ \\
\hline & & $17.1 \%$ & $50.0 \%$ & $28.6 \%$ & $12.5 \%$ & $14.3 \%$ & $25.0 \%$ \\
\hline
\end{tabular}

表 16 類型別の長屋の利用内容 ( 世帯数 $\mathrm{n}=80$ 、長屋数 $\mathrm{n}=99)$

\begin{tabular}{|c|c|c|c|c|c|c|c|}
\hline & & $\begin{array}{l}\text { A.駆体の } \\
\text { 一部を残 } \\
\text { した全面 } \\
\text { 的増改築 }\end{array}$ & $\begin{array}{l}\text { B.複数戸 } \\
\text { 利用 }\end{array}$ & C.n戸1化 & $\begin{array}{l}\mathrm{D} .2 \cdot 3 \text { 階 } \\
\text { の増築 }\end{array}$ & $\begin{array}{l}\text { E.拡張又 } \\
\text { は別棟に } \\
\text { よる増築 }\end{array}$ & 合計 \\
\hline & 専用 & $28 / 35$ & $25 / 35$ & $7 / 14$ & $6 / 8$ & $6 / 7$ & 72/99 \\
\hline & 住尼兼店舗 & $2 / 35$ & $0 / 35$ & $0 / 14$ & $0 / 8$ & $0 / 7$ & $2 / 99$ \\
\hline & 任店夹占喆 & $5.7 \%$ & $0.0 \%$ & $0.0 \%$ & $0.0 \%$ & $0.0 \%$ & $2.0 \%$ \\
\hline 兼 & 住屋尊丁坦 & $2 / 35$ & $1 / 35$ & $3 / 14$ & $1 / 8$ & $1 / 7$ & $8 / 99$ \\
\hline 用 & 住居兼工場 & $5.7 \%$ & $2.9 \%$ & $21.4 \%$ & $12.5 \%$ & $14.3 \%$ & $8.1 \%$ \\
\hline 住 & 住居兼アトリ & $1 / 35$ & $0 / 35$ & $0 / 14$ & $1 / 8$ & $0 / 7$ & $2 / 99$ \\
\hline 宅 & エ・ギャラリー & $2.9 \%$ & $0.0 \%$ & $0.0 \%$ & $12.5 \%$ & $0.0 \%$ & $2.0 \%$ \\
\hline & その他の兼用 & $1 / 35$ & $0 / 35$ & $2 / 14$ & $0 / 8$ & $0 / 7$ & $3 / 99$ \\
\hline & 住居 & $2.9 \%$ & $0.0 \%$ & $14.3 \%$ & $0.0 \%$ & $0.0 \%$ & $3.0 \%$ \\
\hline 店全 & & $0 / 35$ & $3 / 35$ & $0 / 14$ & $0 / 8$ & $0 / 7$ & $3 / 99$ \\
\hline 占告 & & $0.0 \%$ & $8.6 \%$ & $0.0 \%$ & $0.0 \%$ & $0.0 \%$ & $3.0 \%$ \\
\hline & & $0 / 35$ & $2 / 35$ & $0 / 14$ & $0 / 8$ & $0 / 7$ & $2 / 99$ \\
\hline 工境 & & $0.0 \%$ & $5.7 \%$ & $0.0 \%$ & $0.0 \%$ & $0.0 \%$ & $2.0 \%$ \\
\hline & & $0 / 35$ & $3 / 35$ & $1 / 14$ & $0 / 8$ & $0 / 7$ & $4 / 99$ \\
\hline 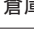 & & $0.0 \%$ & $8.6 \%$ & $7.1 \%$ & $0.0 \%$ & $0.0 \%$ & $4.0 \%$ \\
\hline$\xi \sigma$ & & $1 / 35$ & $1 / 35$ & $1 / 14$ & $0 / 8$ & $0 / 7$ & $3 / 99$ \\
\hline & & $2.9 \%$ & $2.9 \%$ & $7.1 \%$ & $0.0 \%$ & $0.0 \%$ & $3.0 \%$ \\
\hline
\end{tabular}

表 17 「B. 複数戸利用タイプ」の建物どうしの位置関係

\begin{tabular}{|c|c|c|c|c|}
\hline 隣接 & 向こう3軒 & 同じ路地内 & 空堀地区内 & 合計 \\
\hline 2 & 7 & 6 & 1 & 16 \\
\hline $12.5 \%$ & $43.8 \%$ & $37.5 \%$ & $6.3 \%$ & $100.0 \%$ \\
\hline
\end{tabular}

中 7 件) や「家族構成の変化」（7 件中 5 件）が多いのが特徴であり、 利用用途は、 7 件中 6 件が住居専用で 1 件は住居兼工場となっている。

\section{5-3. 接道状況と居住改善実態との関係}

次に類型別の接道状況を見ると（表 18）、全体的には「通路のみ」 の接道条件が最も多いが、一方で「B. 複数戸利用タイプ」では、道 路に面する長屋を所有する世帯も $20.0 \%$ 見られる。これは図 8 に示 すように、道路に面する長屋を店舗として利用し、路地沿いの長屋 
は住居や倉庫として利用するなど、所有する複数の長屋を接道条件 ごとにその利用用途を工夫しているためであると考えられる。なお、 $\mathrm{A}$ 一 F の居住改善は個人の敷地内での改善に留まっており、避難路 の確保など屋外空間に関する課題は改善されないままの状態にある。

\section{5-4. 路地単位特性と居住改善実態との関係}

次に具体的な路地単位特性と居住改善実態との関係の例として、 地形条件や街路形態、個別の地域資源の分布などに特徴を持つ $2 つ$ の路地単位の居住改善手法の実施状況を考察していく（図 9）注11)。

\section{（1）複雑な街路形態で地形条件に特徵を持つ路地単位での実態}

図 9 の(1)に示すこの路地単位では、商店街沿いに店舗を持ち、街 区内部の別の建物である接道不良長屋を住居や倉庫にするなど「В. 複 数戸利用タイプ」による居住改善手法が複数見られる。このような 背景としてこの路地単位では、同じ路地単位の中でも商店街沿いと 街路内部とでは $3 \mathrm{~m}$ ほどの高低差があり、このように平面的に拡張 することが難しい立地条件においては特に、「B. 複数戸利用タイプ」 は居住改善を実現する有効な手段であると考えられる。

しかし一方でこの路地単位は、祠や多数の長屋といった地域資源 を持ちつつも、起伏が大きく建物数も多く、また商店街沿いの店舗 と住居など用途の混在、賃貸と所有物件の混在、多数の袋小路と 2 項道路と通路による複雑な街路構成である。したがって、屋外空間 を含めた根本的な居住改善のためには居住者どうしの連携や協力が 必要不可欠であり、同じ路地単位の中でも、状況に応じていくつか のグルーピングを設けるなどの必要性を示している。

\section{（2）ループ状の街路で地域資源の多い路地単位での実態}

一方、図 9 の(2)に示寸路地単位では、長年住み続けている高齢者 が多く、祠の日常的な共同管理と共に、祠のお祭り、入院時のお見 舞いなど濃密な交流が行われており、また図 9 に示すように、路地 単位内では「A. 駆体の一部を残した全面的増改築タイプ」を中心と した様々な改善手法が行われている。このような背景として、路地 単位内の建物の内、 $92 \%$ が長屋で構成されるなど各世帯は似た空間 条件を持ち、さらに路地単位の入り口には冠木門を持つと共に、街 路形態がループ状で袋小路になっており、路地単位内での一体感に 繋がっていると考えられる。また祠を管理する単位が路地単位と一 致しており、祠に伴う様々な行事と同じ神様に守られているという 意識が強い結束を生夕出し、以上のような状況が居住改善手法に関 する情報共有にも慗がっていると考えられる。

しかし一方でヒアリングによると、この路地単位の持つ強い一体 感や結束は閉鎖的な印象も生み出しており、冠木門や祠などの地域 資源を継承しつつも、開放的な空間構成や新規流入者の受け入れ、 他の路地単位との関係性の再構築などの必要性も示している。

\section{6. 接道不良長屋所有者の今後の意向と新規流入者の流入動向}

最後に本章では、接道不良長屋所有者の今後の長屋の改善・継承 意向と新規流入者の流入動向を見ていく。

\section{6-1. 接道不良長屋所有者の今後の意向}

\section{(1) 長屋の改善・継承意向と後継者の状況}

長屋の改善・定住意向では (表 19)、「今のままで良い」が $64.7 \%$ 、改 修したい」が $17.6 \%$ 、「建替えたい」は 4.7\%となっており、全体 の $87.1 \%$ が定住意向を持っている。

また現在所有している「長屋の後継者の有無」では（表 20）、「後
表 18 類型別の接道状況

\begin{tabular}{|c|c|c|c|c|c|c|}
\hline & $\begin{array}{l}\text { A.駆体の一 } \\
\text { 部を残した全 } \\
\text { 面的増改築 }\end{array}$ & $\begin{array}{c}\text { B.複数戸利 } \\
\text { 用 }\end{array}$ & C.n戸1化 & $\begin{array}{c}\text { D. } 2 \cdot 3 \text { 階の増 } \\
\text { 築 }\end{array}$ & $\begin{array}{c}\text { E.拡張又は } \\
\text { 別棟による } \\
\text { 増築 }\end{array}$ & F.該当無L \\
\hline \multirow{2}{*}{ 通路のみ } & $26 / 45$ & $11 / 30$ & $8 / 15$ & $6 / 8$ & $4 / 7$ & $14 / 23$ \\
\hline & $57.8 \%$ & $36.7 \%$ & $53.3 \%$ & $75.0 \%$ & $57.1 \%$ & $60.9 \%$ \\
\hline \multirow{2}{*}{$\begin{array}{l}\text { 2項道路 } \\
\text { のみ }\end{array}$} & $16 / 45$ & $18 / 30$ & $7 / 15$ & $1 / 8$ & $2 / 7$ & $8 / 23$ \\
\hline & $35.6 \%$ & $60.0 \%$ & $46.7 \%$ & $12.5 \%$ & $28.6 \%$ & $34.8 \%$ \\
\hline \multirow{2}{*}{$\begin{array}{l}\text { 通路+2 } \\
\text { 項道路 }\end{array}$} & $3 / 45$ & $1 / 30$ & $0 / 15$ & $1 / 8$ & $1 / 7$ & $1 / 23$ \\
\hline & $6.7 \%$ & $3.3 \%$ & $0.0 \%$ & $12.5 \%$ & $14.3 \%$ & $4.3 \%$ \\
\hline \multirow{2}{*}{ 道路 (※) } & - & $6 / 30$ & - & - & - & - \\
\hline & - & $20.0 \%$ & - & - & - & - \\
\hline
\end{tabular}

※「道路」に面する長屋は接道不良長屋の対象 99 戸からは外しているが、「B. 複 数戸利用タイプ」では接道不良長屋と共に「道路」に面する長屋を所有する人 がおり、このような実態も重要であると考え、表 18 には「道路」の欄も加えた。
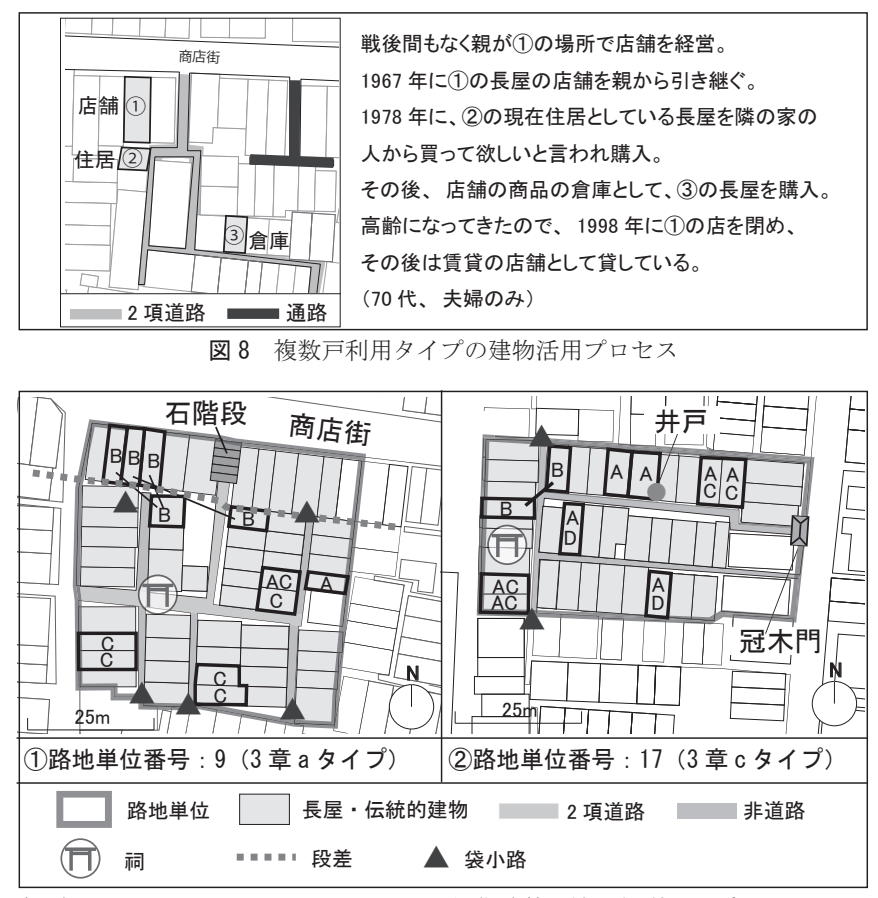

(図中のアルファベットは、5-1 で示した居住改善手法の類型タイプを示してお り、複数あるものは複数の改善手法を持つことを示している）

図 9 路地単位ごとの居住改善状況の例

表 19 所有長屋の改善・定住意向 $(\mathrm{n}=85)$

\begin{tabular}{|c|c|c|c|c|c|c|}
\hline \multicolumn{4}{|c|}{ 定住意向 (87.1\%) } & \multicolumn{2}{|c|}{ 非定住意向 (4.7\%) } & \multirow{2}{*}{$\begin{array}{l}\text { 不明 }(8.2 \%) \\
\text { 分からない }\end{array}$} \\
\hline $\begin{array}{c}\text { 今のままで } \\
\text { 良い }\end{array}$ & Eい & $\begin{array}{c}\text { 増改築した } \\
\text { い }\end{array}$ & $\begin{array}{c}\text { 建て替えた } \\
\text { い }\end{array}$ & 売却したい & 貸したい & \\
\hline $55 / 85$ & $15 / 85$ & $0 / 85$ & $4 / 85$ & $4 / 85$ & $0 / 85$ & $7 / 85$ \\
\hline $64.7 \%$ & $17.6 \%$ & $0.0 \%$ & $4.7 \%$ & $4.7 \%$ & $0.0 \%$ & $8.2 \%$ \\
\hline
\end{tabular}

表 20 長屋の後継者の有無 $(\mathrm{n}=85)$

\begin{tabular}{|c|c|c|c|}
\hline 後継者はいる & 後継者はいない & わからない & 無回答 \\
\hline $22 / 85$ & $20 / 85$ & $41 / 85$ & $2 / 85$ \\
$(25.9 \%)$ & $(23.5 \%)$ & $(48.2 \%)$ & $(2.4 \%)$ \\
\hline
\end{tabular}

継者はいる」は25.9\%、「後継者はいない」は23.5\%、「わからない」 は $48.2 \%$ でり、多くの長屋所有者にとって今後の長屋の継承につ いては不明瞭な状況であることが分かった。

さらに表 21 は、長屋の後継者の状況・意向に関する居住者意見を 表している。ここから、前述の図 20 で「後継者はいる」と答えた所 有者の中でも、(1)ー9)のように後継者が県外に住んでいたり、後継 者の意向はわからない場合、あるいは後継者が相続しても住むつも りはないと思っている場合が複数存在しており、所有者が「後継者 はいる」と思っていることと長屋を継承することは必ずしも一致し ないことを示している。

（2）長屋を維持していく上での問題と必要な支援 
次に「長屋を維持していく上での問題」では（表 22）、「耐震・防 火が不安」（61人）が圧倒的に多く、続いて「高層マンションによ る影響（日照やビル風など）」(24人)、「構造的に改修が困難」(16 人) といった空間的課題が多い。また、「健康上の不安」(18 人)、「維持 修繕費」（15 人）など居住者側の課題と共に、 $4 \mathrm{~m}$ 未満の接道条件で は建替できないといった「建築基準法上の問題」（制度的課題）が（10 人）となっている。なお表 23 と「a. 空間的課題」には、「(1)構造的 に改修が困難」など世帯や建物単位での課題から、「(2)耐震・防火が 不安」など路地単位での改善が必要な課題、さらに「(3)高層マンショ ンによる影響」といった街区や地区レベルなど広域な範囲に及ぶ課 題というように、段階的な課題があることを示している。

さらに「長屋を維持していく上での必要な支援」では（表 23）、「補 助金」が 39 人と最も高く、続いて「特になし」が 34 人となっている。 「特になし」が多い要因としては、居住者の年齢が全体的に高く、既 に改善を行なっていたり、これ以上の改善の必要が無いと捉えてい る世帯が多いこと、さらに接道条件や隣戸と壁を共有しているとい う状況から建替や増改築は難しいとして諦めている世帯も含まれて いることが推測される。

一方で表 23 の中で「隣近所との協力体制」が 14 人となっている ことが注目される。つまり表 24 に示寸居住者意見からも、路地に面 し隣戸と壁を共有する長屋において、増改築や耐震改修、避難路の 確保など、長屋の改善を行う際には隣近所の協力が必須であること を居住者は生活の中で痛感してきたものと考えられ、長屋を維持す るにあたっては、隣近所との協力関係づくりが重要であるといえる。

\section{6-2. 新規流入者の長屋等の利用概要}

以上のように接道不良長屋所有者においては長屋の後継者の不明 瞭さや長屋の維持に関する課題である一方で、空堀地区では近年、 長屋を店舗やギャラリー、事務所や住居として活用する動きが増加 している。そこで以下、個人で長屋等を利用している新規流入者へ のヒアリング調查結果をもとに、長屋等の利用概要を把握していく。

表 21 長屋後継者の状況・継承意向に関する居住者意見

(1)息子は埼玉にいる。たぶん戻ってこない（70 代、夫婦十子、1936 年〜）

(2)息子が売却するのか住むのか分からない (80 代、単身、1945 年い)

(3)車が通れないところには息子は住むつもりはないと思う（70 代、夫婦のみ、1945 年い）

(4)息子と同居しているが、息子は建て直すかもしれない（60 代、夫婦十子十親、1965 年〜）

(5)息子が売却か賃貸にする予定（70 代、夫婦のみ、1954 年〜）

6)後継者が売却する予定 (60 代、単身、1987 年 $)$

(7)弟に相続し、弟は売却する予定（80 代、単身、1945 年〜）

8)息子は近くでマンションを購入しているため後継者はいない（60 代、夫婦のみ、1941 年い）

(9)息子は地区外で持家に住んでおり、賃貸にすると思う。（60 代、単身、1984 年〜）

表 22 長屋を維持していく上での問題 (複数回答可、 $\mathrm{n}=85$ )

\begin{tabular}{|c|c|c|}
\hline \multirow{3}{*}{ a. 空間的課題 } & (1)構造的に改修が困難 & 16 \\
\hline & (2)耐震・防火が不安 & 61 \\
\hline & $\begin{array}{l}\text { (3)高層マンションによる影響 } \\
\text { (日当り、ビル風) }\end{array}$ & 24 \\
\hline b. 制度的課題 & 建築基準法上の問題 & 10 \\
\hline \multirow{3}{*}{ c. 居住者側の課題 } & (1)維持修繥費 & 15 \\
\hline & (2)健康上の不安 & 18 \\
\hline & (3)ライフスタイルに合わない & 3 \\
\hline \multicolumn{2}{|l|}{ d.その他 } & 7 \\
\hline \multirow{2}{*}{\multicolumn{2}{|c|}{ e. 特になし }} & 14 \\
\hline & & 168 \\
\hline
\end{tabular}

表 24 改修時の隣近所との協力に関する居住者意見

\section{・長屋全体で耐震改修することは難しい}

改修などをするときは、迷惑をかけるから協力体制が必要。

・協調で増改築したきいが、隣の世帯と年齢が違い過ぎてなかなかできない。

隣との隌間がないから工事ができない。

協力体制は工事する時には必要。できたら修景を隣と一緒にしたい。乱開発が行なわれな いように地域がもっと連携したら良い。

\section{（1）新規流入者の概要}

新規流入者の年齢(表 25$)$ を見ると、全体 45 人の内の 36 人 $(80.0 \%)$ は 20 代一 40 代の比較的若い世代であることがわかる。また利用物 件の所有関係を見ると（表 26）、住居系では所有物件も見られるが、 多くが貨貸物件である。次に建物利用開始時期を表 27 に示す。新規 流入者を 1990 年以降と定義して調查を行ったが、結果的に 62 件全

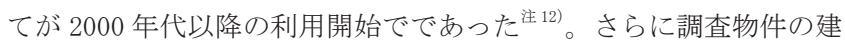
築形態を見ると（表 28）、どの建物用途でも「長屋」の利用が 7 割 以上と高くなっている。また表 29 の調查物件の接道状況からも、路 地に面する割合は住居系の建物用途で多いことがわかる。

\section{（2）新規流入者の長屋等の利用の動機}

次に表 30 は、新規流入者の長屋等の利用の動機を示している。こ れを見ると、全体的には「まちなみの風情が好き」（16 件）が最も

\section{表 25 新規利用者の年齢}

\begin{tabular}{|c|c|c|c|c|c|c|c|c|}
\hline & 20 代 & 30 代 & 40 代 & 50 代 & 60 代 & 70 代 & $\begin{array}{c}80 \text { 代以 } \\
\text { 上 }\end{array}$ & 合計 \\
\hline 独立店舗 & 3 & 11 & 4 & 3 & 0 & 0 & 0 & 21 \\
\hline 兼用住居 & 2 & 3 & 5 & 4 & 2 & 0 & 0 & 16 \\
\hline 専用住居 & 2 & 3 & 3 & 0 & 0 & 0 & 0 & 8 \\
\hline \multirow{2}{*}{ 合計 } & 7 & 17 & 12 & 7 & 2 & 0 & 0 & 45 \\
\cline { 2 - 10 } & $15.6 \%$ & $37.8 \%$ & $26.7 \%$ & $15.6 \%$ & $44.5 \%$ & $0.0 \%$ & $0.0 \%$ & $100.0 \%$ \\
\hline
\end{tabular}

表 26 調查対象者の利用物件の所有関係

\begin{tabular}{|l|c|c|c|c|}
\hline & 独立店舗 & 兼用住居 & 専用住居 & 合計 \\
\hline 賃貸物件 $($ 土地・建物とも) & $21 / 21$ & $11 / 16$ & $6 / 8$ & $38 / 45$ \\
\hline 所有物件 (土地・建物とも) & $0 / 21$ & $5 / 16$ & $2 / 8$ & $7 / 45$ \\
\hline
\end{tabular}

表 27 新規利用者の利用開始時期

\begin{tabular}{|c|c|c|c|c|c|c|c|c|c|c|c|c|}
\hline & $\begin{array}{c}2000 \\
\text { 年 }\end{array}$ & $\begin{array}{c}2001 \\
\text { 年 }\end{array}$ & $\begin{array}{c}2002 \\
\text { 年 }\end{array}$ & $\begin{array}{c}2003 \\
\text { 年 }\end{array}$ & $\begin{array}{c}2004 \\
\text { 年 }\end{array}$ & $\begin{array}{c}2005 \\
\text { 年 }\end{array}$ & $\begin{array}{c}2006 \\
\text { 年 }\end{array}$ & $\begin{array}{c}2007 \\
\text { 年 }\end{array}$ & $\begin{array}{c}2008 \\
\text { 年 }\end{array}$ & $\begin{array}{c}2009 \\
\text { 年 }\end{array}$ & $\begin{array}{c}2010 \\
\text { 年 }\end{array}$ & 合計 \\
\hline 独立店舗 & 1 & 0 & 2 & 2 & 0 & 3 & 1 & 3 & 1 & 7 & 1 & 21 \\
\hline 兼用住居 & 1 & 3 & 1 & 2 & 2 & 3 & 0 & 1 & 1 & 2 & 0 & 16 \\
\hline 専用住居 & 0 & 1 & 0 & 1 & 0 & 0 & 0 & 0 & 3 & 2 & 1 & 8 \\
\hline 合計 & 2 & 4 & 3 & 5 & 2 & 6 & 1 & 4 & 5 & 11 & 2 & 45 \\
\hline
\end{tabular}

表 28 調査物件の建築形態

\begin{tabular}{|l|c|c|c|c|}
\hline & 独立店舗 & 兼用住居 & 専用住居 & 合計 \\
\hline 長屋 & $17 / 21(81.0 \%)$ & $13 / 16(81.3 \%)$ & $6 / 8(75.0 \%)$ & $36 / 45(80.0 \%)$ \\
\hline 伝統的木造建築 & $3 / 21(14.3 \%)$ & $3 / 16(18.8 \%)$ & $2 / 8(25.0 \%)$ & $8 / 45(17.8 \%)$ \\
\hline その他 & $1 / 21(4.8 \%)$ & $0 / 16(0.0 \%)$ & $0 / 8(0.0 \%)$ & $1 / 45(2.2 \%)$ \\
\hline
\end{tabular}

表 29 調査物件の接道状況

\begin{tabular}{|c|c|c|c|c|c|}
\hline \multicolumn{2}{|c|}{} & \multicolumn{1}{|c|}{ 独立店舗 } & \multicolumn{1}{|c|}{ 兼用住居 } & \multicolumn{1}{c|}{ 専用住居 } & \multicolumn{1}{c|}{ 合計 } \\
\hline 接道 & 道路(4m以上) & $14 / 21(66.7 \%)$ & $7 / 16(43.8 \%)$ & $1 / 8(12.5 \%)$ & $22 / 45(48.9 \%)$ \\
\hline \multirow{2}{*}{ 非接道 } & 2項道路 & $3 / 21(14.3 \%)$ & $1 / 16(6.3 \%)$ & $3 / 8(37.5 \%)$ & $7 / 45(15.6 \%)$ \\
\cline { 2 - 6 } & 通路 & $4 / 21(19.0 \%)$ & $8 / 16(50.0 \%)$ & $4 / 8(50.0 \%)$ & $16 / 45(35.6 \%)$ \\
\hline
\end{tabular}

表 30 建物の利用の動機（複数回答あり）

\begin{tabular}{|c|c|c|c|c|c|}
\hline \multicolumn{2}{|r|}{ 利用の動機 } & 独立 & 兼用 & 専用 & 合計 \\
\hline \multirow{9}{*}{ 建築(58) } & & & & & \\
\hline & |オリジナルな空間が作れる & 9 & 2 & 2 & 13 \\
\hline & 家賃が安い & 5 & 3 & 0 & 8 \\
\hline & 古い建物、風情ある建物が好きだから & 3 & 2 & 2 & 7 \\
\hline & 長屋の空間自体が好き & 3 & 1 & 3 & 7 \\
\hline & 住みながらお店など仕事ができるから & 2 & 5 & 0 & 7 \\
\hline & 木造が良かった & 2 & 2 & 2 & 6 \\
\hline & 利用用途と建物の雰囲気が合っている & 3 & 2 & 0 & 5 \\
\hline & 物件規模や建物作りがちょうど良かった & 1 & 3 & 1 & 5 \\
\hline \multirow{9}{*}{ まち(37) } & まちなみの風情が好き & 9 & 6 & 1 & 16 \\
\hline & 買い物が便利 & 1 & 2 & 1 & 4 \\
\hline & 地元の人が良い & 2 & 1 & 1 & 4 \\
\hline & 集客しやすい立地 & 1 & 2 & 0 & 3 \\
\hline & 静か、のんびり、ゆったりしている & 1 & 0 & 1 & 2 \\
\hline & 交通が便利 & 1 & 0 & 1 & 2 \\
\hline & 客層が良い & 1 & 1 & 0 & 2 \\
\hline & 面白い場所だと思った & 2 & 0 & 0 & 2 \\
\hline & 路地が好きだから & 0 & 0 & 2 & 2 \\
\hline \multirow{2}{*}{ その他(3) } & 親族、友人・知人から譲り受けたから & 1 & 1 & 0 & 2 \\
\hline & 親族の家に近いから & 0 & 0 & 1 & 1 \\
\hline
\end{tabular}


多く、次いで「オリジナルな空間が作れる」（13 件）となっており、 歴史あるまちの風情や独自の空間づくりを行えることが大きな魅力 になっている。また、「家賃が安い」(8 件) など経済面での動機と 共に、「古い建物、風情ある建物が好きだから」（7 件）、「長屋の空 間自体が好き」（7 件）など、伝統的な木造建築ならではの空間が魅 力になっている。さらに、「買い物が便利」(4 件)、「集客しやすい 立地」（3 件）、「交通が便利」（2 件）など立地面での利便性も新規流 入者の長屋活用を促している重要な要因の一つであると言える。

\section{（3）建物改修に関する契約内容}

さらに建物改修に関する契約内容を見ると（表 31）、どの建物用 途でも「自由に改修できる」が高い割合を示している。このような 背景として不動産業者へのヒアリングからも、物件の多くは設備や 耐震など様々な問題を抱えた老朽化した建物であり、また大家の多 くは高齢者で改修に伴う費用を出すことは負担であることから、物 件を貸すにあたり大家自身が改修しない代わりに賃貸者による自由 な改修を認めているケースが多いことが明らかになった ${ }^{\text {注 } 13)}$

\section{7. まとめ}

\section{7-1. 調査結果の整理}

以上、本研究を通して明らかになった内容をまとめると次のよう になる。

1) 55 の路地単位の類型結果から、「(1)地蔵又は祠」「(2)起伏」「(3)袋小路」 の 3 つの空間条件を持つ路地単位では個別の地域資源が多数分布し ている。また「(2)起伏なし」のタイプの中には接道不良長屋の割合 が $0 \%$ となっている路地単位が複数見られることから、起伏のある 路地単位は接道不良長屋を残しや寸くしていると言える。一方、類 型別のコミュニティ活動の状況から、「(1)地蔵又は祠」を持つ路地単 位では、以前と現在共にコミュニティ活動が多く見られ、祠や地蔵 の存在が現在でも路地単位内でのコミュニティ活動を継続させてい る重要な資源であるといえる。また近年では新規流入者の流入によ る新たな交流や防災・高齢者福祉に関する活動なども生まれている。 2）接道不良長屋所有者は、路地に面し建替が難しいことや隣戸と壁 を共有するなどの「制度的・空間的制約条件」のもと、老朽化への対応、 狭さの解消、設備の更新、家族構成の変化、機能の追加・変更などの「個 人的な住要求の条件」が重なり、5 類される居住改善が行わ れている。しかし一方で、これら 5 つの居住改善手法はあくまでも 個人の敷地内での改善に留まっており、避難路の確保など屋外空間 に関する課題は改善されないままの状態にある。

3）接道不良長屋所有者は長屋の後継者について不明瞭である場合が 多く、長屋の維持に関しては耐震・防災面等で不安を抱える人が多 いが、同時に隣近所との協力の必要性を認識している居住者が複数 存在する。一方、近年増加している長屋等を活用している新規流入 者の多くは、風情あるまちなみと共にオリジナルな空間づくりがで きることが気に入り建物利用を行っている。このような背景には利 便性の高い立地条件や家債の安さと共に、全体的に建物改修に関寸 る規制が緩く利用者自身による空間づくりの意向を反映しやすい状 況が長屋の利用と更新を促している重要な要因であると考えられる。

\section{7-2. 地域資源を活かした住環境の保全的更新に向けた可能性}

以上を踏まえ、木造密集市街地における地域資源を活かした住環 境の保全的更新に向けた課題と可能性を以下の 4 点にまとめた。
表 31 建物改修に関する大家との契約内容（持ち家 7 件を除く）

\begin{tabular}{|l|c|c|c|c|}
\hline \multicolumn{1}{|c|}{ 契約内容 } & 独立店舗(21) & 兼用住居(11) & 専用住居(6) & 合計(38) \\
\hline 自由に改修できる & $21(100 \%)$ & $10(91.0 \%)$ & $5(83.3 \%)$ & $36(94.7 \%)$ \\
\hline 大家と相談して改修方法を決めている & $0(0 \%)$ & $1(9.1 \%)$ & $1(16.7 \%)$ & $2(5.3 \%)$ \\
\hline
\end{tabular}

1）接道不良、起伏、袋小路といった空間条件は、居住改善を行う上 では制約条件であると同時に、その空間条件が路地単位の特徵をつ くり出したり、コミュニティを育んだり、あるいは長屋や個別の地 域資源を残しやすくしている要因であるとも言える。したがって、 地域資源を活かした保全的更新にあたっては、単に街路の拡幅、起 伏や袋小路を無くして建物更新や避難をしやすくするというのでは なく、路地や既存の地形、街区形態が作り出す風情を継承しつつ、 一時避難所となる空地を点在させたり、袋小路はいざという時には 通り抜けられるようにするなどの工夫が考えられる。

2）また居住改善手法の中で最も多い「A. 駆体の一部を残した全面 的増改築タイプ」は、老朽化や耐震、防災などの改善に関する動機 が多く、現在の法制度では違法とも捉えられる手法であるが、一方 でこのような手法は前面道路側の建物ファサードを残し既存の路地 の持つ風情が保たれるなど、結果的に地域資源の保全にも繋がって いるとも言える。したがって今後は、即時性が求められる場合での 居住者自身による改善を活用した法制度の弾力的運用も重要である。 3）一方で場所ごとに多様な空間条件を持ち、歴史・文化、用途や新 旧住人など様々な要素が混在する空堀のような地区においては、こ の「混在性」こそが地区のポテンシャルを支えているとも言え、地 域資源を活かした保全的更新に向けて地区全体を一律の手法によっ てルール化を行おうとするのではなく、個人レベルと地区全体を繋 ぐような新しいシステムづくりが重要であると考えられる。

具体的には、従来の地区計画などで定められている敷地範囲の基 準よりもさらに小規模なスケールでの対応を可能にすることや、地 形条件や街路形態、長屋や個別の地域資源の分布などが異なる中で、 同じ地区内でも複数の範囲が異なるルールや基準によって同時並行 で住環境改善の活動を行えるようにすることが重要である。つまり、 祠や地蔵、路地などによって育まれてきたコミュニティや、地形や 街路条件などを共有する居住者や権利者が集まり、路地単位ごとの 特性に応じた将来像や保全す心゙き地域資源、居住改善手法、路地の 管理に関するルールなどを協議していく必要があると考えられる。 4）さらに、居住者の多くが高齢化し長屋の後継者についても不明瞭 であることからも、今後次の世代に相続する際に、長屋等の地域資 源が消滅し駐車場化や高層マンション化など大きな空間的変化が地 区内で連鎖的に起こることが予想される。このような状況の中、近年、 比較的若い世代がまちなみの風情やオリジナルな空間づくりが行え ることなどを評価して長屋を創造的に活用しており、これらの新規 流入者の存在が、今後、世代間交流や防災、福祉など、地域が抱え る課題の改善にも重要な役割を果たす可能性を持つと考えられる。

したがって、これまで負の遺産として捉えていたような老朽化し た物件や接道不良長屋も、利用者自らが手を加え創造性が発揮でき る資源として価值を見い出すと共に、建物内だけでなく路地整備な ど「屋外空間と一体になった」様々な改善手法を柔軟に受け入れ、 後継者のいない長屋への若年世帯の利用を支援するような新たな仕 組みづくりも重要であると考えられる。 


\section{謝辞}

空堀地区内の居住者や事業者、HOPE ゾーン協議会役員、地元不動 産業者、空堀住環境魅力づくり研究会、からほり俱楽部、大阪市役 所をはじめ、本研究にご協力頂きました方々に心より感謝致します。 また本調查にあたって山本延行氏（CASE まちづくり研究所）、田中 順己氏（福井大学）のご協力を得ましたことを記し感謝いたします。

\section{注}

注 1）本研究における「接道不良」とは、 $4 \mathrm{~m}$ 以上の道路に接していないことを 指し、 $4 \mathrm{~m}$ 未満の街路を「路地」と呼ぶことにする。また本研究における「接 道不良長屋」とは、 $4 \mathrm{~m}$ 未満の路地のみに接する長屋を指すものとする。

注 2)「HOPE ゾーン事業」とは、大阪市が 2004 年度から地域の魅力を活かした まちな㘳景事業として取り組んでいる事業で、これまでに空堀地区を含め 大阪市内の 6 つの地区が選定されている。また本研究における 55 の路地単 位は、基本的には 2003 年度に大阪市が空堀地区で HOPE ゾーン事業の整備方 針を策定する際に選定されたものを取り入れており、空堀地区の中でも特に 長屋や個別の地域資源が多く残る路地単位を中心に選定されている。なお、 路地単位の範囲設定の基淮としては、基本的には $4 \mathrm{~m}$ 以上の道路に到達寸る までの連続した路地を一つの単位としている。また、現時点では既に長屋が 取り壊され空地化やマンション化が進行している路地単位もある。

注 3) なお本研究では、地蔵、祠、冠木門、石盢や石階段などの個別に分布寸 る地域資源を便宜上、「個別の地域資源」と呼ぶことにする。

注 4）本研究における「新規流入者」とは、1990 年以降に空堀地区内の建物利 用を始めた人のことを指す。また表 2 の「萌練惣」とは、地元のまちづくり 団体である「からほり俱楽部」によって長屋等を活用した 3 つの複合施設で、 これらの物件はからほり俱楽部が大家からいったん借り上げ、建物内を小さ く区切り転貸先を募集するといら形で運営されている。したがって、本研究 では個人契約による長屋利用者を対象とするため「萌練慜」を除き、「独立 店舗」「兼用住居」、「専用住居」の 3 つを調查対象事例として分析を行う。 そして本研究では、事務所やアトリエ、ギャラリーなど、住居以外の建物用 途を持つものも「店舗」と呼び、これに基づき店舗のみの用途を持つものを 「独立店舗」店舗と共に居住機能を持つものを「兼用住居」と呼ぶこととし、 居住機能のみを持つものを「専用住居」と呼ぶことにする。

注 5）空堀地区内の建物棟数は 7328 棟、その内、長屋数は 1450 戸、調査を 行ったブロックでの長屋数は 722 戸、その内の接道不良長屋数は 572 戸であ る。また調査を行った接道不良長屋のうちの $63 \%$ 筑 100 年以上であり、 老朽化が進行していることが推測される。さらに空堀地区内では、高層マン ションの建設などにより比較的若い世代の新規世帯も多く流入しており、 近年、地区内の世帯数と人口は増加傾向にある（H12 年度 : 3282 世帯・6984 人、H17 年度: 4390 世帯・ 8224 人、H 22 年度: 4617 世帯・ 8281 人、国勢調査)。 しかし一方で、特に街区内部の接道不良長屋では居住者の高齢化が進行して おり、空堀地区内の 65 歳以上の居住者割合は $21.8 \%$ （中央区全体 $18.2 \%$ 、 大阪市全体 $20.1 \%$ 、H17 年度国勢調查）となっている。

注 6）これまでに HOPE ゾーン協議会では部会を立ち上げ、路地保全や秩序ない 大規模開発を防ぐためルールづくり等を進めようとしてきたが、複雑な状況 が絡む中、現時点ではルール制定等の目処は立っていない。

注 7) 長屋戸数では大阪府が全国の都道府県の中で最も多く、また空堀地区は 大阪市内や中央区内の中でも特に長屋が多く残る地区であり、空堀地区内の 建物の内、約 2 割が長屋で構成されている。

注 8）本研究では長屋を棟単位でカウントせずに住戸単位でカウントしている。 注 9）路地単位の選定について、本来なら 55 の路地単位全てを分析すべきであ るが、居住者の不在や拒否等によりヒアリングが困難な路地単位もあり、こ こでの分析は路地単位でのコミュニティに関する内容であることから複数の 居住者から話を聞くことができた路地単位を対象としている。また類型ごと の傾向を把握するため各類型タイプから少なくとも 1 つ以上を抽出してい る。さらに予備調查を行った結果、特に「(1)地蔵又は祠あり」の路地単位で コミュニティ活動に特徴があることが分かったため、「(1)地蔵又は祠あり」 で母数の多い a と c の路地単位を中心に選定している。

注 10) 空堀地区のコミュニティ活動に関する基本的な組織として、10 軒程度 を一つの単位とし回覽板等を回寸「班、班が複数集まって構成される「町会」、 町会が複数集まって構成される「連合振興町会」がある。なお路地単位の中 には班の範囲と一致するものも一部見られるが、班の設定範囲は複雑であり、 複数の班と路地単位が一致するものも多い。またコミュニティ活動の単位と しては、班で独自に行っているものもあれば、複数の班で行っているもの、
あるいは町会単位や連合振興町会、有志による単位など㥞々である。このよ うな状況の中、本研究では、空間条件を共有する居住者間での交流に特に着 目しているため「路地単位」から考察を行う。

注 11) なお各路地単位の状況は複雑でどれも個別であると言え、路地単位特性 と居住改善実態との関係を考察しその因果関係や全体的傾向を明確に示寸こ とは極めて難しいといえる。しかしここで取り上げる 2 例は、8つの類型夕 イプの中でも特に地域資源を多く残寸 $\mathrm{a}$ と $\mathrm{c}$ タイプであり、袋小路や地形条 件等によって空堀地区の空間面での特徴を分かりやすく示寸と共に、空間条 件による路地単位としての緑まりがあり、路地単位特性との関係から居住改 善を考えることが特に有効であると考えられるため、この 2 例を取り上げる。 注 12）地元のまちづくり団体である「からほり俱楽部」による長屋再生活動が 開始されたのは 2001 年であり、空堀地区内での近年のこうした新規流入者 の集積には、からほり俱楽部の活動が促進の役割を果たしていると考えられ る。なおこの団体は、空堀地区界隈の良さを活かし住みやすく魅力あるまち の創造を目差し活動しており、これまでに長屋等の再生による複合施設の運 営やアートイベントなど空堀地区を拠点に様々な活動を展開している。

注 13) ただし住居として貸し出している物件の中には、屋根や躯体など必要最 低限の部分は大家が改修しているものもある。なお「自由に改修できる」と なっている物件の殆どは、退去時に元の状態に戻すことも不要となっている。

\section{参考文献}

1）増井正哉・西川幸治・谷直樹 - 太田潤 - 内村俊彦 - 大倉克仁 : 長屋街区 形成過程の史的考察 : 大阪・谷町の長屋と路地の研究その 1 、日本建築学会 近畿支部研究報告集、計画系、pp. 469-472、1988

2）高木真人・森田孝夫・阪田弘一: 京都東山における路地の空間特性と安 心感からみたセキュリティ空間としての可能性、日本建築学会計画系論文集、 N0. 652、pp. 1349-1354、2010.6

3) 川窪広明 : 空堀商店街周辺の町屋と祠の変遷 : 1977 年と 2003 年の調查に 基づく比較、日本建築学会近畿支部研究報告集、計画系、pp. 69-72、2004

4）吉野国夫：コミュニティの原風景一大阪で発見した濃密な路地の近所付き 合い『路地からのまちづくり』、2006、学芸出版社

5）川崎興太 : 路地保全を前提とした木造密集市街地における居住環境整備方 策に関する研究 - 東京都中央区月島地区における 3 項道路型地区計画の初 動的な実績と効果 -、日本都市計画学会都市計画論文集、No. 41-3、 pp. 1013-1018、2006

6）丸登健史・浦山益郎・松浦健治郎：路地保全を前提とした路地と沿道建築 物が一体となった路地空間のマネジメントに関する研究ー街なみ環境整備事 業が適用された長野県木曽町「福島宿周辺地区」を事例として一、日本都市 計画学会都市計画論文集、No. 43-3、pp. 463-468、2008

7）高野哲矢・野澤康 : 既成住宅地における良好な住環境形成に資するデザイ ンガイドのあり方に関する研究、日本都市計画学会都市計画論文集、No. 443、pp. 439-444、2009

8）真野洋介・武田友佑・小林愛佳・佐藤滋 : 墨田区一寺言問地区における市 街地更新、住宅供給実態と地域内の住み替えの関係性一木造密集市街地にお ける住環境整備と居住支援プログラムの連携に向けての基礎的研究一、日本 都市計画学会都市計画論文集、No. 38-3、pp. 37-42、2003

9）松本暢子：東京下町の住宅密集地域における建築更新活動と家族の居住継 承に関する研究、日本都市計画学会都市計画論文集、pp. 445-450、1994

10）金胃錫・高見沢実：密集市街地整備のための連担建築物設計制度の運用に 関する研究、日本都市計画学会都市計画論文集、No. 40-1、2005

11）田中友章：連担建築物設計制度の活用による協調的個別更新の可能性、日 本都市計画学会都市計画論文集 273 卷、pp. 59-64、2008

12）小林由佳・高見沢邦雄・饗庭伸：密集市街地における建替え動向と協調建 替え概念の検討 - 墨田区京島地区での考察を中心に一、日本都市計画学会都 市計画論文集、No. 38-1、pp. 13-24、2003

13）藤井一成・ 三輪康一 ・ 安田丑作・ 未包伸吾 - 栗山尚子: 密集市街地におけ る協調的住環境改善手法とその評価に関する研究、日本都市計画学会都市計 画論文集、No. 42-1、pp. 87-92、2007

14）脇田祥尚：コンバージョンによる長屋と路地の空間更新 一中崎町界隈（大 阪市北区）を事例として一、日本建築学会計画系論文集、N0.660、pp. 287294、2011.2

15）野澤千絵・ 小浦久子 ・鳴海邦碩 : 被災地の住宅の個別再建による街区内細 街路の変化に関する研究、日本都市計画学会都市計画論文集、No. 33、 pp. 847-852、1998

16）空堀地区 HOPE ゾーン整備方針策定調查報告書、大阪市、2004.3 